\title{
REPORT OF AN EXCURSION TO BRIDPORT, BEAMINSTER AND CREWKERNE.
}

April 9Th to i4th (EAster), igi4.

By L. Richardson, F.R.S.E., F.G.S., Director of the
Excursion.

APRIL 9TH.

Chideock Quarky Hill and Symondsbury.

THE official party travelled from Paddington by the $10.30 \mathrm{a.m}$. train and arrived at Bridport at $\mathbf{r} .55$ p.m. Here a number of Members from other parts joined those from town.

Headquarters were at the Bull Hotel, Bridport.

Mr. Douglas Leighton acted as Secretary of this excursion.

The excursion was to be held in one of the prettiest parts of Dorset, but rain had fallen continuously for many days, and when the Members entered the district at Maiden Newton prospects of fine weather appeared very remote indeed. However, at 2.30 p.m., when a start had to be made for Chideock Quarry Hill, the rain had ceased, a strong wind had arisen, and sunlight penetrated between the scurrying clonds, lighting up portions of the diversified landscape of western Dorset.

From the Bull Hotel the Members walked westwards along the Lyme Road. The conical Colmer's Hill, which is so conspicuous when looking westwards down West Street, Bridport, and at once attracts the attention of newcomers to the town, was remarked on at an early stage of the walk. It was explained that its conical portion was composed of Bridport Sands, and that the hard capping of Inferior-Oolite rocks had, geologically speaking, only just been removed.

At the end of the hamlet called "West Road," in Symondsbury parish, the Members left the main road, followed the by-lane to Symondsbury for some one hundred and fifty yards, and then turned up the trackway that leads to the quarry on Chideock Quarry Hill.

A very strong wind was blowing, so before climbing the exposed hillside the Director called a halt. Very briefly he reminded them of the main objects of the excursion, namely, to enable those participating in it (I) to become acquainted with the general geology and geography of the district, and (2) to pay. particular attention to the Inferior Oolite and contiguous deposits in this part of England.

Two miles to the east was seen the town of Bridport with the tumulus-like Shipton Hill or Beacon (559 ft., composed of Upper Greensand resting on Fullers' Earth) conspicuous beyond.

Bridport is situated upon the Middle Lias (see Sheets I 7 
and 18 of the Geological Survey, Old Series) and near the outlet of the River Brit, which, with the River Char, shares the drainage of what, for the lack of a better name, may be called "The Vale of Bridport."

On the east side of the Vale the hills stretch from the coast at Burton Bradstock to Beaminster and thence westwards to the neighbourhood of Broadivindsor.

Owing to a great east and west fault, which runs immediately to the south of Shipton Gorge, the Forest Marble beds in that neighbourhood have been let down against the Bridport Sands. The beds thus dip in a northerly direction, which means that the strike is approximately east and west, and therefore the principal hills and valleys have a similar alignment.

From Shipton Gorge, however, as far as Mapperton, near Beaminster, the lower portion of the hills is composed of Bridport Sands capped with Inferior Oolite. The Inferior Oolite has a prevalent easterly inclination. The beds are greatly affected by faults; headward-growing streams have actively incised the Inferior-Oolite platform, and now remarkably deep valleys separate the Inferior-Oolite-capped tabulated promontories and fault-block hills.

Between Beaminster and Broadwindsor faults-with a more or less east-and-west alignment--have again greatly affected the rocks, as may be well seen when looking from the elevated Inferior-Oolite-capped Whaddon Hill to the quarries in the equivalent rock low down at Horn Park.

Between Shipton Gorge and Broadwindsor the Inferior Oolite is succeeded by the Fullers' Earth-a thick deposit of clay, which gives rise to cold heavy ground that leads up to the slopes where the Upper Greensand crops out. Above comes the Cbalk. Shipton Hill is a prominent outlier of Upper Greensand : Eggardon and Hackthorn Hills, weli-known promontories of the Chalkthe former crowned with a fine prehistoric camp.

Between Burton Bradstock and Shipton Gorge it should be observed that, instead of the Upper Greensand resting directly upon Fullers' Earth, as is the case at Shipton Hill, it is separated therefrom by the Forest Marble, and, in places, Cornbrash and Oxford Clay. This indicates that faulting took place before the Upper Greensand was laid down as well as after.

From near Broadwindsor, around in a rough semicircle as far as Thorncombe Beacon on the coast, are the great hills of Lewesdon ( $894 \mathrm{ft}$.), Pilsdon (the highest hill in Dorset- $9 \circ 9 \mathrm{ft}$.), Lamberts Castle ( $842 \mathrm{ft}$.), Haddon and Stonebarrow, Golden Cap (6I9 ft.), and Thorncombe Beacon (509 ft.) -hills, with the exception of the first and last, composed of Upper Greensand resting on Middle Lias. The reason why the Greensand is found resting on successively older beds from east to west-on Fullers' Earth at Shipton Hill, on Bridport Sands at Thorncombe 
Beacon, on Middle Lias at Stonebarrow, Lower Lias at Lyme Regis and Keuper Marls at Seaton in Devonshire-is because these older rocks were inclined in an easterly direction and subjected to denudation before the newer Cretaceous deposit was laid down unconformably upon them.

The River Char has broken through the group of hills to the west of Stonebarrow and Haddon Hill, has cut through the Middle Lias and created a hollow in the Lower Lias. It seems to be working slowly eastwards and to be encroaching upon the area drained by the Brit system.

The principal work that is being done by the Brit system is also in an easterly direction. The Mangerton River, the most important eastern tributary of the Brit, separates into a number of streamlets, which are rapidly growing headwards, wearing through the hard platform formed of Inferior-Oolite rock and quickly excavating deep valleys in the subjacent Bridport Sands. It is in this neighbourhood, between Powerstock and Maiden Newton, that the only really interesting piece of river-development in this district may be studied (see page 65 ).

Another fine view over the Vale of Bridport is to be obtained from Whaddon Hill (see page 74 ).

The Members then ascended the trackway to the quarry. Before it reaches the quarry this trackway passes through two cuttings. In the right-hand side of the first, yellow sands and an occasional sandburr belonging to the Bridport Sands are exposed. In the same side of the second cutting, at the top of the bank, is slightly disturbed rock of scissi hemera (see Fig. 3, page 50). Below it is the equivalent to the Rusty- or Foxy-Bed of the BurtonBradstock district, of Whaddon Hill and the Conegar-Hill section, Broadwindsor. It rests upon a very fossiliferous sandstone, which is exactly like the equivalent bed below the Rusty Bed at Whaddon Hill, having white marly portions and many specimens of ammonites, belemnites, Variamussium laviradiatum (Waagen), Serpula tricarinata auctt., Rhynchonella pentaptycta S. Buckman, etc. In the opposite bank, low down (in bed $7 c$ of Mr. S. S. Buckman's record), ${ }^{*}$ many coarse-ribbed aalensis-like ammonites were found.

The Members then went into the quarry-the only one now in work on the hill.

The Wild Bed (see Fig. 3), although joined on to the Red Bed or Building Stone, was readily identified. It is of a lightyellow colour and therefore very distinct from the rich brown ironstone of the Red Bed. The portion of murchisonce hemera (xxiii.) was found to be packed with ammonites, and many specimens were obtained. Here and there attached to the surface of the Murchisona-Bed was observed white, fine-textured limestone with large brown oolite-granules. Probably it is of discite date,

-Quart. Fourn. Geol. Soc, vol. lxvi (rgro), p. 64.

Proc. Geol. Assoc., Vol. XXVI, Part I, I9I5.] 


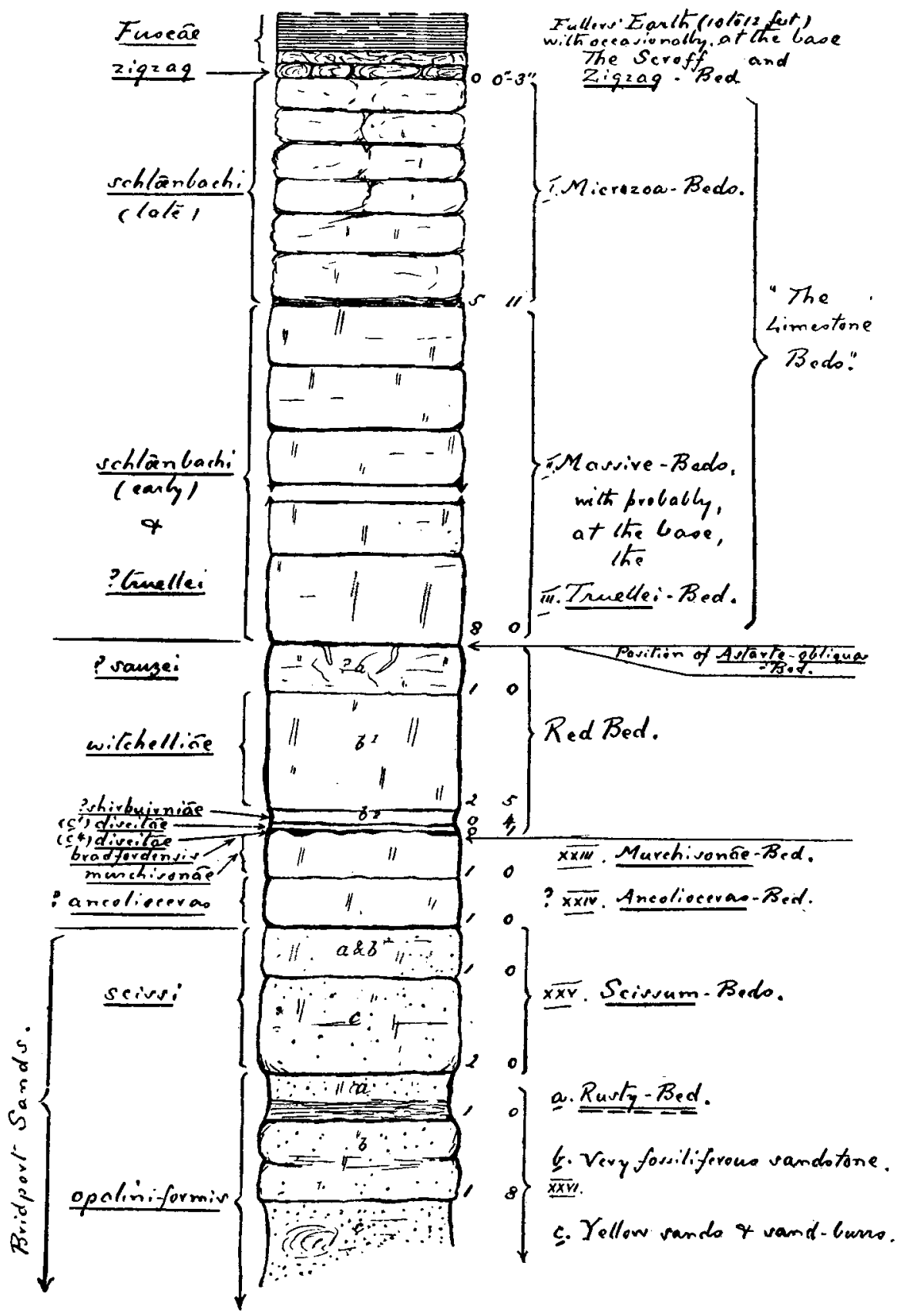

Fig. 3.-Vertical Section of the Inferior Oolite and Contiguous Deposits AT CHIDEOCK QuARRY HILL.-L. Richardson. 
and it is certainly non-sequentially related to the Murchisonce-Bed below. Mr. S. S. Buckman, however, has seen "ironshot sandy stone, with Ammonites of the Ludzigia-gradata type, often in a perished condition" in irregular hollows of the Murchisonce-Bed. This means that rock was laid down here during the bradfordensis hemera, but was broken up before or early in the discita hemera. At Burton Bradstock the erosion that took place early in the discitce hemera effected the destruction of rock, not only of bradfordensis date, but of whatever representative there was there of the Murchisonce- and Ancolioceras-Beds as well. The residue subsequently became cemented together and enclosed in what is now known as the "Yellow Conglomerate-Bed." One feature, therefore, of the Chideock-Quarry-Hill section is the presence of well-developed beds of murchisone and ? ancolioceras hemera, which are absent from the Burton Bradstock district.

Interest was exhibited at the highly ferruginous character of the ironstone. A typical piece, with a fragment of a species of Witchellia in it, has been examined microscopically by Prof. S. H. Reynolds, who reports :

"This rock is mainly composed of smail oolite-granules of fairly uniform size, all completely replaced by ferric oxide. In the matrix between the granules the remains of crinoids are readily recognisable."

The horizon at which the Astarte-obliqua. Bed would have been found here, had it been developed, was pointed out.

Limestone, probably of truellei hemera, in the form of rubble, caps the section.

To stand up, let alone collect, was rendered difficult by the strong wind which swept across the hill. Nevertheless, some collecting was done, after which the Members were conducted to an old and almost wholly overgrown working a little to the west. Here, numerous pieces of limestone with crowds of specimens of a rather small form of Terebratula sphceroidalis auctt. were observed. The Director said that Mr. S. S. Buckman had found no evidence for the Truellei-Bed on this hill, but as masses of a similar form of Terebratula characterized that bed at Burton Bradstock it seemed probable that it was present here also.

The walk was then continued in a northerly direction. Beyond a wall is a long line of old quarries, from the partly overgrown sides of which project masses of rock. The beds are very similar to those worked in the quarry, but lower strata are also exposed. They are at a higher level than those in the quarry in work, being to the north of a fault which traverses the hill with an east-and-west alignment, on the south side of which the strata have been lowered.

A feature that at once attracts the eye is the extremely level surface of one bed. This is the top of the Wild Bed. To its waterworn surface is attached coarsely oolitic rock, less bleached but otherwise similar to that $\left(c^{4}\right)$ seen in the quarry. In places 
both it and the faces of the Murchisone-Bed displayed in fissures are stained crimson by chalybeate waters that were charged with iron which was derived from the ironstone-beds that were formerly present above.

The Members then walked across the hill in a north-easterly direction, across the down land, from which-now that it had cleared up-magnificent views were obtained over the surrounding country.

An old quarry was shortly reached in which were seen Fullers' Earth clays resting on "The Limestone Beds" (= TopLimestones). A slip had recently occurred and it was noticed that at that particular place The Scroff, of fusce hemera, and the Zigzag-Bed were wanting. The whole of the Inferior-Oolite limestone exposed in this quarry (with the exception of the sporadically developed Zigzag-Bed) is of schlonbachi hemera, and contains the usual fossils. A part of the more rubbly upper portion is contemporaneous with the beds that contain sponges so abundantly at Burton Bradstock.

The Members descended the northern slope of the hill and took the turning for Symondsbury. This lane is very deeply sunken near its commencement in the rather indurated yellow Bridport Sands. It reminds one of the Bradford-Abbas " hollowway "in the Yeovil Sands between Bradford Abbas and Yeovil.* Colmer's Hill was passed on the right.

Just before Symondsbury village was entered the "JunctionBed" of the Middle and Upper Lias was seen in the mural sides of the lane-cutting.

The Director said that, very briefly, the sequence between the Murchisone-Beds (sensu lato) and the sandy beds of the Middle Lias at Chideock Quarry Hill and the coast was as follows :

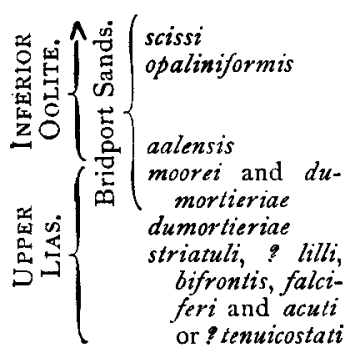

$$
\begin{aligned}
& \text { Scissum-BEDS . }
\end{aligned}
$$

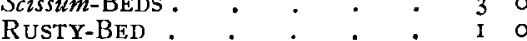

$$
\begin{aligned}
& \text { Very fossiliferous sandstone : } \cdot \text { I } 8 \\
& \text { Sandburrs and sand . } \quad . \quad 38 \\
& \text { Sandburrs, sandrock and sand } \quad \begin{array}{rr}
39 & 8
\end{array} \\
& \text { Sands and sandburrs : about... I17 } \\
& \text { Down-Cliffs Clays . . . 70 } \\
& \text { JUNCTION-BED. In its more com- } \\
& \text { plete form this bed comprises } \\
& \text { Striatulus-, Bifrons-, and Falcifer- } \\
& \text { Beds, and two layers of Marlstone } \\
& \text {-(a) Rhynchonella-serrata-Marl- } \\
& \text { stone and } \\
& \text { (b) Rhynchonella - media - Marl- } \\
& \text { stone. On an average its tbick- } \\
& \text { ness is . . . . . } 2
\end{aligned}
$$

* See Proc. Cotteswold Nat. F.C,, vol. xviii, part 2 (Ig13), pl. xii, fig. 2. 


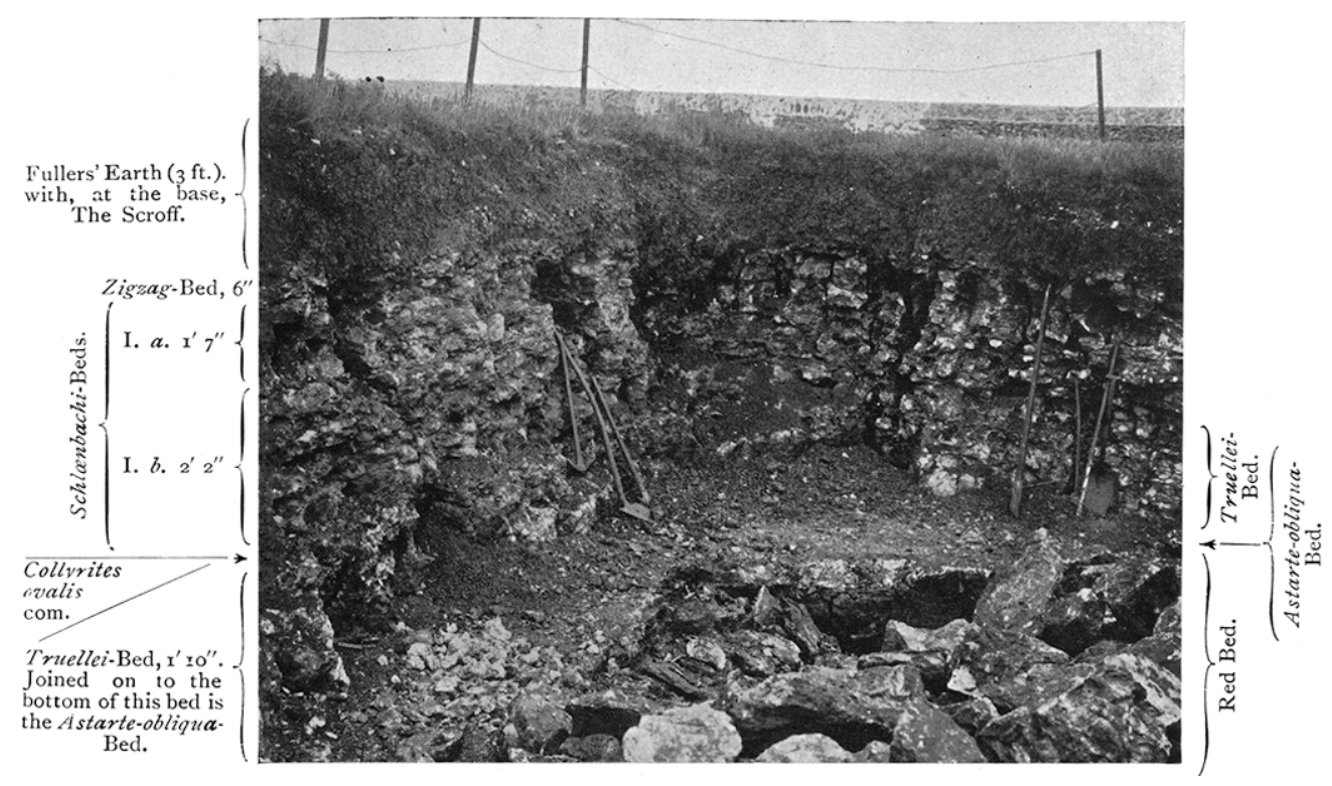

The Allotments Quarry, Burton Branstock.-L. Richardson. 
As remarked by Mr. Buckman the Down-Cliffs Clay was not to be found on the top of the representative of the Junction-Bed in this lane: "it has either passed laterally into yellow sands, or it is absent" (Quart. Journ. Geol. Soc., vol. lxvi, I910, p. 62).

Particular attention was drawn to the fact that Grammocerasstriatulum-forms occur in one of the upper layers of the JunctionBed-below $70 \mathrm{ft}$. of Upper-Lias clays and the whole of the Bridport Sands. In the Cotteswold Hills, at Wotton-underEdge, the Striatulum-Bed occurs above the Cotteswold Sands and Upper-Lias clay.

The Junction-Bed is worked in a quarry near by, and is exposed-above the Sandy Beds of the Middle Lias (which look precisely like the Bridport Sands)-in the lane to the east of the village.

Sloe Hill, Symondsbury, was next visited. It is capped with Oolite and the sequence of beds seen in the quarry is similar to that already observed on Chideock Quarry Hill. The lowest rock seen, the top-portion of layer $c$ of the Scissum-Beds, contains specimens of Terebratula conglobata Desl., not uncommonly. Bed $\operatorname{xxv} a$ and $b$, is similar as regards faunal and lithic characters to its equivalent at Chideock Quarry Hill and Chiselcombe Quarry, Loders Cross. The chief point to notice, however, is that the Murchisone-Bed is still present as a well-defined stratum.

An analysis of the ironstone (Red Bed) from Symondsbury has been made by $\mathrm{Mr}$. Dick and published by the late $\mathrm{H}$. B. Woodward. Woodward says :-

It may be reckoned that the rock would yield 24 to 26 per cent. of metallic iron. The presence of so much carbonate of lime [lime I9 per cent., carbonic acid 18.7 per cent.] would not necessarily be injurious, as the material would act as a flux in the smelting process. ${ }^{*}$

The geographical extent of the ironstone is, of course, very small; too limited to justify it being worked as an jron ore.

The hotel was reached at 6.30 p.m.

\section{APRII, IOTH.}

\section{BURTON BRADSTOCK AND SHIPTON GORGE.}

On Friday the Members left the hotel at 9.30 a.m, and drove to the quarry in the allotments at Burton Bradstock. From the bridge over the railway, West Bay (or "Bridport Harbour," as it used to be called) was seen. The official programme did not include an excursion to the little port, but at one time or another during their stay in Bridport most of the Members were able to visit it.

To the west of the harbour, at the end of the little esplanade, and forming the eastern extremity of West Cliff (or "Watton

* "The Jurassic Rocks of Rritain," vol iv. "The Lower Oolitic Rocks of Engl ard (Yorkshire excepted)," r894, pp. 498, 499. M/em. Gen. Suru. 
Hill," as Wright called it*) is an isolated mass of Bridport Sands. The late Mr. H. B. Woodward wrote concerning it :

The Fuller's Earth is dragged up along the fault-plane, and the Sand is also broken and disturbed, while traces of Inferior Oolite have in places been wedged in. $\dagger$

The most striking feature in the coast scenery of this neighbourhood, however, is the remarkable precipitous East Cliff. It is composed of yellow sands with layers of sand-burrs and bands of calcareous sandstones, from roo to $\mathrm{I} 20 \mathrm{ft}$. thick, and capped-only at the very top-with Inferior Oolite. As remarked by Mr. Woodward, the

remarkable banded appearance is due to the influence of atmospheric denudation, the harder layers of calcareous sandstone standing out in relief. A slight inland dip in the strata tends to keep the cliffs perpendicular. . . .

A fine view of the East Cliff is to be obtained from the end of the pier at West Bay.

Near the end of the East Cliff is a coombe ("The Coombe "), from the east side of which, looking westwards, is obtained an excellent view of Golden Cap, while from the west side looking east is seen the western portion of Burton Cliff. The break in the cliffs between the East and Burton Cliffs is that through which the River Bride (or Bredy) obtains access to the sea.

This gap and the flat alluvial ground between it and Burton are very well seen from the high road about half a mile before entering the village.

Passing through the village the Members drove to a little beyond, to the Allotments' Quarry. Here the sequence from the Fullers'-Earth clay to the I ruellei-Bed (vide Fig. 4) was seen. In IgI 2 the Astarte-obliqua-Bed was the lowest rock visible, but in I913 the Red Bed had been worked, and numbers of the curious limonitic concretions, called "snuff-boxes" by the quarrymen, were lying about. On the present occasion Fullers'-Earth clay had been removed in order to obtain more stone, and had been dumped in the quarry, with the result that the Truellei-Bed was the lowest rock exposed.

The Larkfield Quarry-that where Mr. S. S. Buckman obtained many of the details of the Top-Beds which he published in his generalized section of the Inferior Oolite in the neighbourhood of Burton Bradstock-was pointed out. It was not visited, however, because it has been long abandoned and while the beds from the top portion of the Red Bed to the Fullers'-Earth clay are still to be seen they are not sufficiently well exposed for satisfactorily collecting from.

From the Allotments' Quarry the Members walked to the Cliff-Hill Section+, where the sequence from the lower part of the Schlombachi-Beds (see Fig. 4) well down into the Sands

* Quart. Journ. Geol. Soc., vol. xii (5 856), p. 3ro.

+ "The Jurassic Rocks of Britain, etc.," vol. iv. (1894), p. 56, Mem. Geol. Surn'

$\ddagger$ Proc. Cotteswold Nat. F. C., vol. xviii, pt. i (1912), plate vi. 


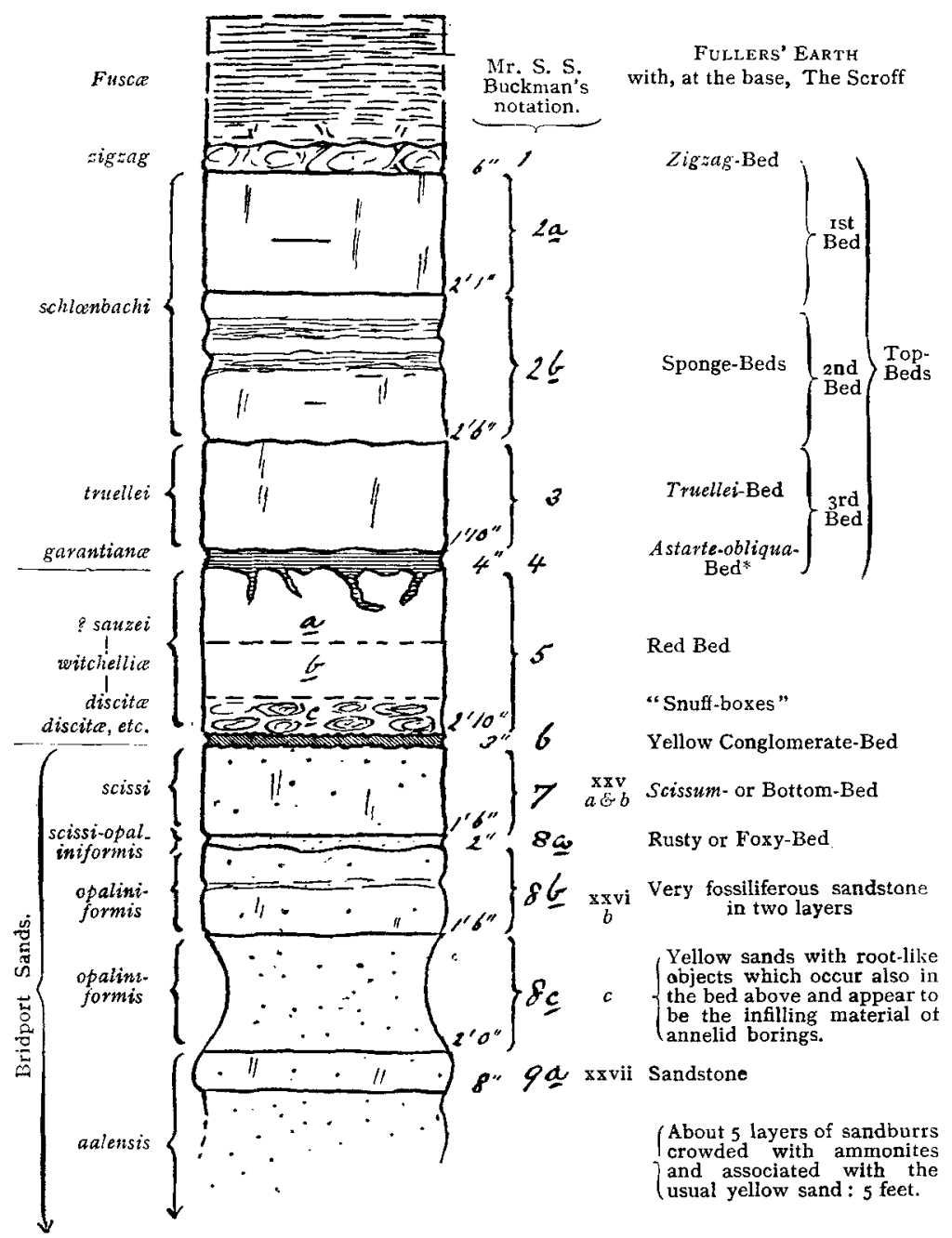

* Here and there between the main Astarte-obliqua-Bed and the Red Bed is conglomerate in which pieces of ironshot rock, not unlike that constituting layer $b$ of the Red Bed, are a frequent constituent.

Fig̣. 4.-T'tertical Section of the Inferior Oolite and Contiguous DEPOSITS EXPOSED AT BURTON BRADSTOCK.-L. Richardson. 
is admirably displayed. When the road was lowered about the year I 882, Dr. M. Poignard collected a large number of fossils from the beds that were cut through.* The Members did not tarry here longer than was necessary to make out the succession of deposits, because it was not possible for them to make any extensive excavations in search of fossils. In the OpaliniformeBeds (XXVI $b$ and $c$ ) curious root-like objects were observed. They appear to have originated as sand-with a harder cementing material than that of the deposits in which they occur-which had found its way down annelid-borings.

The road leads up through the Cliff-Hill cutting on to the top of the cliff. At the foot of the cliff lies the Chesil Bank, $\uparrow$ stretching from West Bay, two miles to the west, right away ( $\mathrm{r} 5$ miles) to Portland-which could be easily discerned-in the south-east.

Near Burton Villas the origin of the White Nantilus-Bed of Mr. S. S. Buckman was discussed.

Numerous pieces of the rock were seen lying about on a sort of pathway that affords a short. cut from the road to the beach. It was observed that the very white aspect of the stone was due to weathering of the surface.

As noticed by Mr. Buckman the pieces are in part "lithographic "stone and in part sandy rock. He therefore thought that the rock was a conglomerate. Round the corner, however, similar rock was seen in situ, in the Bridport Sands.\$ The "lithographic" portion was obviously introduced as fine material by percolating waters. It occurs sometimes in thin irregular layers in the sandstone, at others in irregular masses ; while in one place deposit had been made on the side of a face of rock which was exposed down a fissure.

Mr. Buckman also noticed a small amount of rock, which he described as being more like the "sandy rock" associated with the "lithographic" stone in the upper part of the Red Bed.

The Director said that Mr. H. L. Hawkins, of Reading, had sent him a Terebratula from near the top of the Red Bed, which was embedded in a matrix, a part of which was ironshot, like the middle part of the Red Bed, $b$, and a part impure "lithographic" stone. There is no doubt that here and there below the main Astarte-obliqua-Bed and sometimes joined on to the top of the Red Bed is conglomeratic rock (see page 58 ), and it was probably from this horizon that the piece of "lithographic" stone came that yielded to Mr. Buckman fossils indicative of late niortensis or garantiance hemera.

Prof. S. H. Reynolds has very kindly examined microscopic-

\footnotetext{
* Proc. Geol. Assoc., vol, ix, pt. 4 (1885), p. 204.

+ Prnc. Geol. Assoc., vol. ix, pp. 204-205.

†Quart. Journ. Geol. Soc., vol. Ixvi (19io), pp. 69-7 r.

\$ See Proc. Cotteswold Nat. F.C., vol. xviii, pt. I (1912), pl, iv, fig. 2.
} 
ally one of the two pieces of "lithographic" stone that Mr. Buckman gave to the Director. These two particular pieces probably come from the top of the Red-Bed horizon. Prof. Reynolds reports :

The main part of the rock is seen in a thin section to be an almost structureless calcitic mudstone, showing ill-defined banding and enclosing small angular quartz-grains thinly-scattered. Part of the hand-specimen has a reddish tint, and this is seen to be due to innumerable little patches of ferric oxide not developed in relation to any organic remains.

To sum up, the Director stated that it was clear that the so-called "lithographic" stone did not occur as an ordinary stratum or conglomerate. They were close to a fault; one having a throw-according to Mr. Buckman--of $200 \mathrm{ft}$. or more, by which Fullers' Earth and Forest Marble had been let down against the Oolite and Sands. He was of opinion that waters, highly charged with calcareous matter, had percolated through the Oolite and Sands and that deposition had taken place wherever conditions were favourable. "The "lithographic" stone might be found associated with fossils of any hemera. Up to date, it had been found ( $I$ ) near the top of the Red Bed, and (2) in the Bridport Sands.

During the walk along the beach to the place where the huge masses of Oolite have fallen bodily down, the precipitous cliffs of Bridport Sands, capped with Oolite and Fullers' Earth, were much admired. The position of the Red Bed could be easily made out by its red stain.

Considerable discussion took place as to the origin of the layers of sand-rock and sandburrs ; but no satisfactory explanation was forthcoming. The hard beds are highly calcareous, and water exuding from their neighbourhood has frequently formed a lace-like travertinous deposit pendent from one hard stratum to another. In places percolating waters, charged with bicarbonate of lime, have originated in the softer intervening deposits a kind of box-structure, some said very similar in appearance to that known in the Hastings Sands.

Arrized at the tumbled blocks the Members saw that masses had fallen bodily down, in which it was possible to identify the various beds from the Sands to the Fullers' Earth. Each bed could be conveniently measured and fossils collected.

A vertical section of the Inferior Oolite and contiguous deposits to be seen here was given in our Circular and is reproduced (with some slight alterations) on page 55 .

The Director reminded the Members that Mr. S. S. Buckman was the first to describe satisfactorily the sequence in the neighbourhood of Burton Bradstock. Many other geologists, including Thomas Wright, E. C. H. Day, W. H. Hudleston, and the late H. B. Woodward had studied the beds, and the published results of their work were very useful, especially when the in- 
formation was sufficiently detailed to make it possible to be sure to which particular bed they were referring.

The various beds were easily made out with the aid of the section, Fig. 4. Particular attention was drawn to certain beds. Thus it was pointed out that while at Chideock Quarry Hill, between the coarsely-oolitic rock that forms the basal portion of the Red lied and the Scissum-Beds, were the Murchisonce and ? Ancolioceras-Beds, here at Burton Bradstock there was only a thin layer of conglomerate called the Yellow Conglomerate-Bed, on an average some 3 inches thick. From this conglomerate have been obtained fossils suggesting the destruction of deposits of very late scissi.? Ancolioceras, murchisona, bradfordensis, concavi and very early discitce hemerz. The matrix of this conglomerate is a greenish rock, here noticeably deficient in brown oolite-granules.

Above is the Red Bed. The bottom portion, $c^{4}$, is an extraordinarily oolitic limestone, the granules being numerous, large and brown, becoming slightly smaller above $\left(c^{1}\right)$ and enclosing curious large flattened ferruginous concretions, locally called "snuff-boxes." On upturned weathered surfaces of the bed these "snuff-boxes" present a remarkable appearance. Their date of formation was probably late discite. When these concretions are broken it is found that they comprise a nucleus (a rolled piece of rock, or more frequently a waterworn and bored piece of shellMyoconcha, Ctenostreon, etc.), and alternating layers of Serpulae and mud, the whole impregnated with ferric oxide.*

The succeeding layer of the Red Bed, $b$, is a hard crystalline limestone with numerous brown "iron grains," which give the rock a brown and sometimes "pink" appearance. It is of early sauzeizeitchellice hemera, $\dagger$ and is succeeded by layer $a$-an extremely hard grey crystalline limestone practically made up of broken pieces of crinoids. The surface of the bed is irregular- "pitted" -waterworn, and the top portion is pierced with long irregular perforations down which a now bright-red material has found its way.

Unfortunately the precise date of layer $a$ of the Red Bed is not known, but it is either late reitchellice or sauzei.

As already mentioned (page $5^{6}$ ), here and there in irregularities in the surface of the Red Bed and below the main Astarte-obliqua-Bed is conglomerate of which pieces of an ironshot rock, not unlike that constituting layer $b$ of the Red Bed, are a frequent constituent. Also, either associated with this conglomerate or embedded in the lower portion of the Astarteobliqua-Bed one occasionally finds "snuff-boxes" and illpreserved limonitic ammonites which are probably remanié. Mr. F. L. Spath writes (in litt., roth June, rgi4) :

\footnotetext{
* It is noteworthy that in the deposit of the same age in the Cotteswold Hills, namely, the Buckmani-Grit (and especially in th: lower portion), a similar species of Serpula abounds.

$\dagger$ Probably Witchillice.
} 
With regard to the ammonites that I collected [on the excursion] from the rock associated with the top of the Red Bed, there are only three more or less determinable (limonitic) specimens: Polyplectites sp. (P. aff. linguiferus d'Orb.), ?niortensis [hemera] ; Steph. cf. umbilicum (Quenstedt), ? blagdeni; and Emileia aff. brocchi (Sow.) ? sauzei.

This conglomeratic, rock reminds one of the "Irony-Bed" of Louse Hill, near Sherborne.

Mr. Buckman has written: "all the available"evidence points to the [Red] bed being a conglomerate." There is conglomerate - as mentioned above-occasionally attached to the top of the Red Bed, and when the Yellow Conglomerate-Bed is ill-developed, yellow-coated pebbles of that bed--ordinarily enclosed in the distinctive matrix of that deposit-are embedded instead in the basal portion of $c$; but the rest-the bulk of the bed, comprises three regularly-stratified layers- $-a, b$ and $c$.

The three main layers of the Red Bed, $a, b$ and $i$ are very distinct from one another at the Chiselcombe Quarry, Loders Cross, on the Bridport-Dorchester road (see page 63 ).

The change as regards lithic structure from the hard grey crystalline limestone of layer $a$ of the Red Bed, to the brown, more crumbly rock of the Astarte-obliqua-Bed is very noticeable. Also, while in the grey bed recognisable fossils are the exception, here beautifully-preserved gastropods and many species of lamellibranchs are the rule. Montlivaltia lens $\mathrm{E}$. and $\mathrm{H}$. and Patoceras aff. annulatum (d'Orb.) are notable zonal fossils.

The Director said that it was not now necessary to remind anyone interested in Inferior-Oolite stratigraphy of the fact that the most widespread crust-oscillation that took place in InferiorOolite times occurred just before the garantiance hemera. Another movement took place about half-way through that hemera, and in the Dundry-Timsbury district of Somerset, suitable conditions obtained for the accumulation of the Dundry Freestone. Then came a time (early truellei) when throughout the Dundry-MidfordCotteswold area corals flourished and the interesting Upper Coral-Bed, with its microzoa, was formed. He had found, however, no trace of this Upper Coral-Bed between Bruton, in Somerset, and the English Channel.

In the Burton-Crewkerne district the Top Limestones succeed the Astarte-obliqua-Bed.

The most interesting feature of the Top Limestones in the neighbourhood of Burton and Shipton Gorge is the occurrence in the portion of sihlonbachi hemera of Sponge-Beds, ${ }^{*}$ rich in specimens of sponges, microzoa and, at Shipton Gorge in particular, of polyzoa. Far away, at Stinchcombe Hill, near Dursley, in Gloucestershire, $\dagger$ some marly beds on the same horizon have yielded a rich collection of microzoa.

Dr. G. J. Hinde has figured many sponges from Burton Cliff

* These beds resemble in many respects the Faringdon sponge-bed (Greensand).

t Proc. Cottesteold Nat. F. C., vol. xvii, pt. I (rgro), pp. IIO-II I. 
and Shipton Gorge in his well-known "Monograph of the British Fossil Sponges "-the majority new to science.

Many specimens of sponges were obtained by the Members and of Serpula from the top of the underlying Truellei-Bed-of a species, which, the Director said, was very characteristic of this horizon.

The Zigzag-Bed, which completes the Top Limestones, is a very distinct bed-a hard, rubbly, bluish-hearted limestone with nany little ammonites, mostly of the genus Oecotraustes.

After having collected many fossils, the Members continued their walk westwards to the break in the cliffs at Burton Freshwater where the River Bride has cleared for itself a channel through the Chesil Bank. Then they turned inland and made for Burton village.

On the way the Director pointed out Wennet Hill and the small section in the Sands at its foot which gave to Mr. Buckman "evidence tor aalensis beds at the top and for moore $i$ beds some few feet lower down." He (the Director) said that in times past there were several quarries in work in the Top Limestones a short way inland from the East Cliff, but that now these and that on Wennet Hill-from which crowds of fossils, such as Terebratula sphceroialilis auctt., Ter. phillipsi Morris, Ter. stephani Dav., Collyrites ovalis (Leske), Pygorhytis ringens (Ag.) Stomechinus bigranularis (Lam.), etc., had been obtained-were overgrown.

The Anchor Inn, Burton Bradstock, was reached at I p.m.

The walk to Shipton-Gorge village was commenced at I.45 p.m. The route followed was over the eastern end of North Hill (37 r ft.) to Bennett's Hill Farm. The dip of the Fullers'-Earth and Forest-Marble beds is to the north. Owing to the heavy and continuous rain that had fallen the clay-ground was very wet.

From the top of the North Hill fine views were obtained in all directions, and a more ideal day could not have been desired. Shipton church-tower showed up in the depression to the northeast and "the Beacon" beyond.

A short deviation was made to the head of Bonscombe in order to see certain physical features. The top-edges of the combes, where the Oolite occurs, are often curiously sharp, while the level ground originated by that rock is for the most part under the plough. Deep down in the combe, east of the farm, are springs coming from the base of the Sands-presumably from at or near their junction with some Upper-Lias clay. The Sands would appear to be about $\mathrm{I} 35 \mathrm{ft}$. thick here, at least that is about the depth from the base of the Oolite to the springs.

A short walk across fields strewn with pieces of flint and chert brought the Members to the quarry near the New Inn, Shipton Gorge, or "Peas-Hill Quarry" as it is locally called.

The beds exposed belong to the Top limestones, but here 
EXCURSION TO BRIDPORT, BEAMINSTER AND CREWKERNE. 61

include two noticeable bands of grey marl. It was from this quarry and from these grey marls that Mr. E. A. Walford obtained in 1885 about fifty different species of polyzoa and noticed also "echinoderms, small Brachiopods (Crania, Thecidea, etc.), Sponges, and Foraminifera."

Mr. Walford gave a record of the beds exposed in the quarry and the Director said he was able to testify to its extreme accuracy.

The beds so rich in small fossils, which Mr. Walford wrote "apparently belong to the Zone of Ammonites parkinsuni," are now definitely known to be of schlanbachi hemera. When Mr. Walford visited the quarry the relation of the Top Limestones to the beds below could not apparently be ascertained.

When the hard rock-floor of the quarry was examined, however, it was found that it contained small sharp-keeled ammonites (? Canavarella sp., etc.) like those occurring in the Rusty Bed and subjacent sandstone at Burton Bradstock. In fact, the Top Limestones rest directly upon rock of opaliniformis hemera without the intervention of any Scissum-, Yellow Conglomerate-, Red, or Astarte-obligua-Beds.

At the eastern end of the village, in a short cutting on the Askerswell Road, a similar relationship of the Top Limestones to the Sands was seen.

Barely 250 yards to the north of the last section, however, in the garden of the house called "Smacombe," is a face of rock in which, between the deposit containing ammonites, indicative of opaliniformis hemera, and the Top Limestones, are the ScissumBeds and Red Bed, together $2 \mathrm{ft}$. 8 in. thick. The Rusty Bed is readily detected: it is a deep-brown clayey marl, $x$ to 3 in. thick, and full of ammonites-? Canavarella aff. toma S. Buckman, involute Plsydellia, Cypholioceras opaliniforme S. Buckman, Alocolytoceras toniatum (Pompeckj), etc.

The absence of beds from between the Top Limestones and Opaliniforme-Beds at the two sections seen before that at "Smacombe" may be partly accounted for by movement having occurred in garantiance or early truellei hemera along an anticlinal axis orientated east-south-east and west-north-west, passing through Shipton village, and what deposits there were having been removed.

The next stop was at the partially overgrown face of rock in the old quarry, on the right-hand or east side of the road before commencing the descent to Innsacre Farm.

This section is interesting for several reasons. The Astarteobliqua-Bed is typically developed, crowded with fossils, and is sometimes joined on to the base of the Top Limestones and at others on to the top of the Red Bed. The Red Bed is, on an average, I ft. 4 in. thick, and comprises three distinct layers, $a$, * Quart. Journ. Geol. Soc., vol. xlv (x889), p. 562. 
$b$ and $c$, as on the coast. In the southern portion of the section, the bluish oolitic rock, $c$, more coarsely oolitic in the lower portion, does not contain any "snuff-boxes," but in the northern portion it has thickened to 4 in. and contains them abundantly. Limonite-coated pebbles, etc., such as are characteristic of the Yellow-Conglomerate-Bed, occur in places embedded in the bottom portion of this rock. Scissum-Beds, to a depth of $2 \mathrm{ft} .3$ in., were seen. The upper foot and a half is equivalent to the "Blue Bed" ( $a$ and $b$ ) of Chiselcombe Quarry, Loders Cross. It is important to notice that the Scissum-Beds are now thickening; at Burton Bradstock the massive bed is $\mathrm{I} \mathrm{ft} .6 \mathrm{in}$. thick, while at Upton Farm, Uploders (see page 64), the beds are seen for a depth of $6 \mathrm{ft}$. without any sign of the Rusty Bed.

A climb up the very steep south-western side of Green Hill brought the Members to a quarry, in work, in the Top I imestones. In places, in the flocr of the quarry, may be seen the surface of the hard, grey crystalline limestone, layer $a$ of the Red Bed. Above, joined on to the base of the Top Limestones, is muddy pale-yeliow limestone well ironshot with brown oolite-granules. This is the representative of the Astarte-obliqua-Bed. The bottom bed ( $\mathrm{ft}$. $8 \mathrm{in}$.) of the Top Limestones is of a lighter colour than the succeeding rocks and is the Truellei-Bed. Here it was pointed out that the prominent grey marly beds of the Peas-Hill section were not developed; but it was mentioned that the marl and rubble in the upper portion of the quarry-face were on their horizon.

The view from the field between the quarry and the gate giving access to the main road (Bridport to Dorchester) was much admired. Westwards, beyond the combe, were seen Watton and Coneygar Hills, with Colmer's and Chideock Quarry Hills to the left of them, and the hills beyond.

Stonyhead Quarry was seen but not entered, because the Director said that the beds exposed in it were similar to those that had just been studied on Green Hill.

The Members then walked into Bridport, passing on the way King Charles' Stone, ${ }^{*}$ and arrived at the hotel about $6.3 \circ$ p.m.

April i I TH.

Loners Cross, Vinney Cross, Uploners, and Powerstock.

On this day the Members left the hotel at 9.30 a.m. and drove past the Stonyhead Quarry to Loders Cross on the Dorchester Road. The brakes then returned to Bridport.

On the south side of the road is a quarry in which is seen Fullers' Earth ( $2 \mathrm{ft}$. to $3 \mathrm{ft}$.), with The Scroff at the base, the Zigzag"Charles II., on September 23rd, 165 , rode over from Charmouth and halted at the
"George Inn," Bridport. Finding the yard full of Cromwell's men he escaped along the Dorchester road, turned down Lea Lane (where the stone mentioned above is placed), stayed a night at Broadwindsor, returned to Trent, and finally got across the Channel to. France from Shoreham. 
Bed (6 in.), and Schlonbachi-Beds (similar to their equivalent at Green Hill), to a depth of $9 \mathrm{ft} .6 \mathrm{in}$.

The beds require no particular comment, except that the limestone immediately below the Zigzag-Bed contains gastropods not infrequently.

The quarry on the north side of the road-- that into which the Members went--is known as the "Chiselcombe Quarry." There are two portions of this quarry: an upper, in which the Schlanbachi-Beds (similar to their equivalents on the other side of the road) have been worked; and a lower, in whick: the beds from the Truellei-Bed (the bottom-bed of the Top Limestones) to well into the sandy Scissum-Beds, are being actively quarried (Pl, 7).

The Astarte-obliqua-Bed was pointed out, and attention called to the rich yellow ochreous (oxidised iron-pyrites) inclusions associated with it because they are a very characteristic feature of this bed.

The three divisions of the Red Bed, $a, b$ and $c$, are very distinct from one another here, more so than anywhere else in the district, and similar to their equivalents on the coast. No ammonites have been obtained from the hard grey crystalline limestone-layer $a$. From $b$ several specimens of an Emileia intermediate between $E$. brocchi (Sow.) and E. grandis $(\mathrm{Qu}$.) have been obtained, which Mr. Spath says might be expected equally well in sauzei as in zeitchellia. The rock composing this bed is very pretty to look at when freshly-fractured. The oolitegranules have been replaced by ferric oxide, have a pyritic lustre, and are irregularly-distributed in the greyish limestone.

A specimen of the bottom-stratum, $c$, of the Red Bed has been submitted for microscopical examination to Prof. Reynolds. He reports that it is

a strongly oolitic rock, the granules-which show very well marked concentric structure-being completely replaced by ferric oxide. The matrix, which is almost entirely made up of fragments of crinoids and other fossils, is also iron-stained.

The oolite-granules in the lower part of this layer $\left(c^{4}\right)$ are even larger than in the upper. Crowds of the curious "snuff-boxes" were seen in situ, but few were lying about on the spoil-heaps.

The Yellow Conglomerate-Bed was observed in fissures in the bed below and is similar to its equivalent on the coast.

In places attached to the top of the "Blue Bed" is ironstained rock containing ammonites considered to be indicative of ancolioceras and very late scissi hemeræ. It is important to notice that here the Yellow Conglomerate-Bed is distinct from the rock with the "snuff- boxes" above and from the conglomeratic layer (attached to the "Blue Bed ") below.

The "Blue Bed" of the quarrymen separates into two layers. Both are full of fossils, including species of Lioceras similar to 
those in the equivalent bed at Chideock Quarry Hill and Sloe Hill, Symondsbury. Below the "Blue Bed" is sand-rock, still Scissum-Beds, seen to a depth of I ft. 8 in.

From Chiselcombe Quarry the Members walked to that at Vinney Cross. On the way the Limekiln Quarry -the section in which was described by Hudleston-was pointed out. It is not now in use. At the top, however, can still be seen the Fullers' Earth, below which are the Top Iimestones, similar to their equivalents at Loders Cross and Green Hill. The upper beds have on their weathered surfaces many interesting fossils : gastropods, Crania sp., radioles of Acrosalenia sp., of Cidaris sp. (cf. C. yeovilensis Wr.), C. bouchardi Wr., ? Rhabdocidaris sp., etc.

At Knight's Quarry, Vinney Cross, the ferruginous surface of the Red Bed $(a)$ was pointed out in the floor of the quarry. Above it is the extraordinarily fossiliferous bed for which this quarry is widely known, the Astarte-obliqua-Bed. The main bed is I ft. I in. thick. On top is marl, I in. thick (with the usual rich yellow ochreous inclusions), partly formed-as in the case of the celebrated Marl-Bed of Bradford Abbas-by the decay of the underlying bed. Search should be made in the Marl-Bed for the rare brachiopod Dictyothyris morieri (Desl.)* and in the main bed for specimens of the curious uncoiled cephalopod Patoceras aff. annulatum (d'Orb.).

Above the rock of garantiance hemera was recognised the paler-coloured Truellei-Bed, followed by the remaining Top Limestones, similar to their equivalents in the preceding sections. The dark-brown clayey soil at the top is residual Fullers' Earth.

From Knight's Quarry the Members walked to that at the back of Upton Farm. This is the section referred to by Hudleston as showing "pretty much the same sequence as at Vetney [Vinney] Cross "-presumably at the Limekiln Quarry.

In this old quarry at Upton Farm, as the photograph reproduced in Plate 8 shows, the various beds are very well displayed.

The Director pointed out the Yellow Conglomerate-Bed filling in fissures and inequalities in the Scissum-Beds below. Later in date, but associated with this Yellow Conglomerate-Bed, is very coarsely oolitic rock similar to that forming the lower part of $c\left(c^{4}\right)$ at Chiselcombe Quarry. In places it has found its way down crevices in the Scissum-Beds.

A well-marked parting is next encountered, and above it comes the deposit equivalent to the greater part of $c$ at Chiselcombe. It is somewhat different, however; it is similar to the rock of the "Fossil-Bed" of Bradford Abbas, and, like that bed, contains Rhynchonella forbesi Dav., and Terebratula eudesiana

* Mr. Tutcher informs me that he has a fine specimen of this brachiopod from here in his collection, 


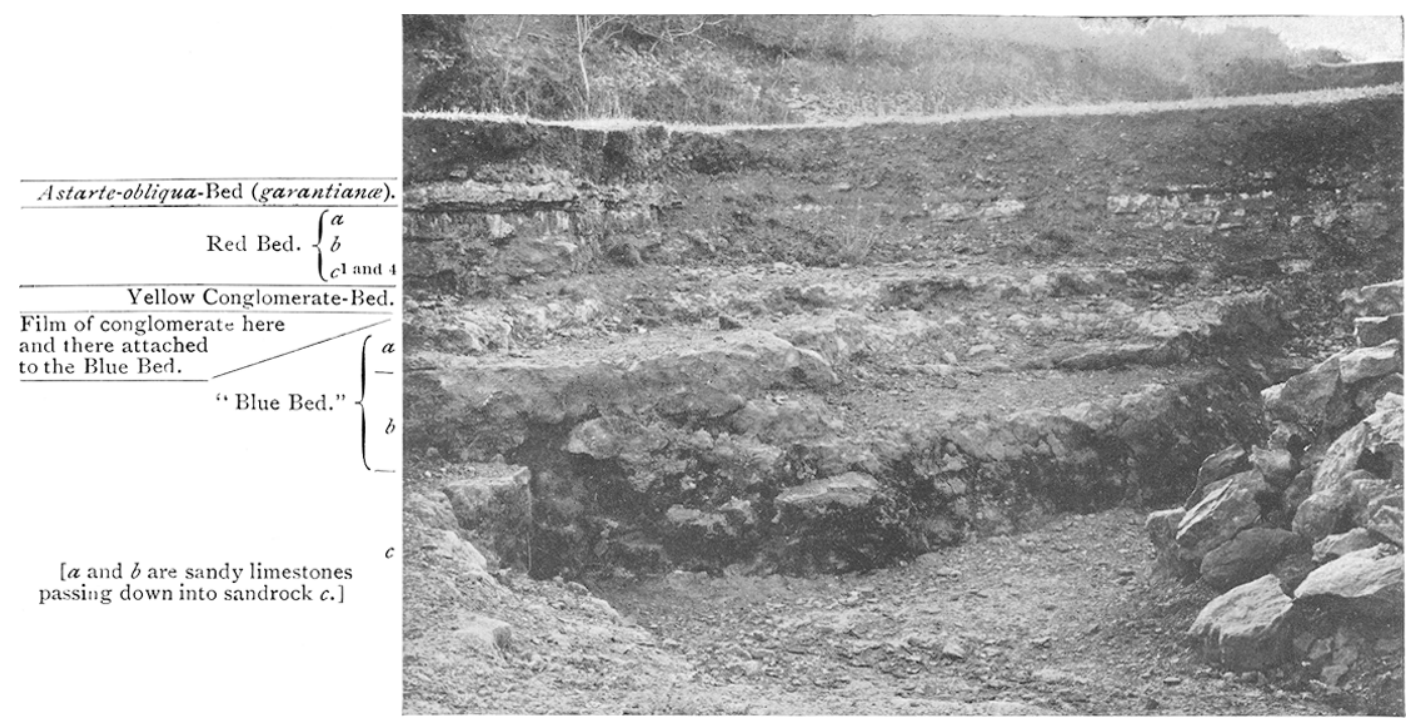

Chiselcombe Quarky, Loders Cross, Near Bridport.-L. Richardson. 
EXCURSION TO BRIDPORT, BEAMINSTER AND CREWKERNE. 65

S. Buckman. "Snuff-boxes" are few and small and occur at the base.

The representatives of layers $b$ and $a$ of the Red Bed are very apparent.

Succeeding the Red Bed is the Astarte-obliqua-Bed, which is well-developed and in two portions, as at Knight's Quarry, Vinney Cross.

A considerable number of fossils was obtained here, and after about an hour's work the members went to the Crown Inn for a bread-and-cheese lunch.

The first quarry visited after lunch was the Bell Quarry Here crowds of large "snuff-boxes" were seen in situ, and also in the ruts of the cart track where they had been put by the quarrymen.

The lowest rock seen is sand-rock of scissi hemera. To it succeeds the Blue Bed (in two layers $a$ and $b$ ), also scissi. Here and there, joined on to its top, is rock, conglomeratic, containing evidence of derived fossils from deposits of late scissi and ancolioceras or early murchisone hemeræ.

The limonite-coated pebbles so characteristic of the Yellow Conglonerate-Bed, are here embedded in the very coarsely-oolitic rock, $c^{4}$.

The Red Bed is $3 \mathrm{ft} .3$ in. thick and composed of layers $a, b$, and $c$.

The Astarte-obliqua-Bed is sometimes absent, but where present will be found attached to the base of Truellei-Bed and quite typical. Marl, with a large quantity of rich yellow ochreous matter, occurs in a conspicuous layer below it. Above, are the usual Top Limestones, and-at the northern extremity of the quarry - the Fullers' Earth.

The steep ascent of Welcome Hill was then negotiated and the pleasant upland reached. By the wall at the head of the combe, that opens out to the west of Powerstock, a halt was called.

Under the hedge on the right an old quarry-face was pointed out in which it was said was to be seen the bottom portion of the Top Iimestones, separated from the upper portion of the Red Bed by the Astarte-obliqua-Bed, 4 in. thick, quite typical, and crowded with gastropods-Alaphrus acmon (d'Orb.), Pleurotomaria palamon d'Orb., Trochus duplicatus Sow, etc.

The Director also pointed out the general geology and geography of the country within view, and then dealt at some length with a little piece of river development that was in progress in the country between here and Maiden Newton.

If the geological map (Old Series, Sheet i 8 ) be consulted, it will be observed that the River Frome, which flows from Evershot past Maiden Newton to Dorchester, Wareham and Poole Harbour, is joined at Maiden Newton by the River Hooke, coming from a PROC. GEOL. Assoc., VOL. XXVI, PART I, I915.] 
westerly direction. This tributary rises on Rampisham Down, flows south-eastward past the village of Hooke and Lower Kingcombe to Toller Porcorum, and thence eastwards to Maiden Newton. At Toller it is joined by a small stream, which collects its waters from the neighbourhood of Toller Common. Growing headwards, that is, working its way backwards, north-eastwards from the neighbourhood of Powerstock, are several tributaries of the Mangerton River-itself a tributary of the Brit. The eastward-growing tributaries of the Mangerton River are continuing their encroachment upon the area drained by the Hooke River and its tributaries, and causing that stream to decrease in volume and to "retreat."

At the present time the River Hooke between Tollerand Maiden Newton is a comparatively small stream in a broad valley. It "misfits" the valley, and-as in the similar case of the Coln, near Cheltenham-meanders in level, alluvial meadows in the valley. Necks have been cut through and ox-bows formed; while spurs, originated by the once greater river, have in places been scarped. By degrees the stream growing north-eastwards from Powerstock will work further in that direction, will capture the portion of the River Hooke that remains to the north-west of Toller, will drain off its waters south-westwards, and continue its advance up the valley to Maiden Newton. Here, presumably, it will effect a greater capture-that of the River Frome above Maiden Newton. The valley with the Frome in it at Maiden Newton looks as if it had once accommodated a river with a larger volume of water in it than the present one.

This distribution of the streams in the Powerstock-MaidenNewton district is especially interesting when it is compared with the present distribution of the streams in the CheltenhamAndoversford district. If Catisbrook be replaced by Charlton Abbots, Maiden Newton by Andoversford, Eggardon Hill by Leckhampton Hill, and the valley between Toller and Maiden Newton by the "Chelt Gap," it will be seen that with the farther headward growth of the main tributary of the Mangerton River at Powerstock a distribution of streams will be effected that in many respects resembles that which obtains in the CheltenhamAndoversford district of the Cotteswolds.

As there was ample time a visit was paid to Powerstock to see the Church and have tea.

At 4.45 p.m. the members arrived at the quarry at Powerstock Station. At the extreme western corner of the quarry is seen Fullers' Earth. It contains Ostrea knorri Voltz and other fossils, most of which have specimens of the foraminifer, Webbina, attached to them. The Fullers' Earth rests on an extraordinarily fossiliferous gravelly deposit (about 3 inches thick and of zigzagr hemera), which in turn reposes on the usual Schlonbachi-Limestones. 


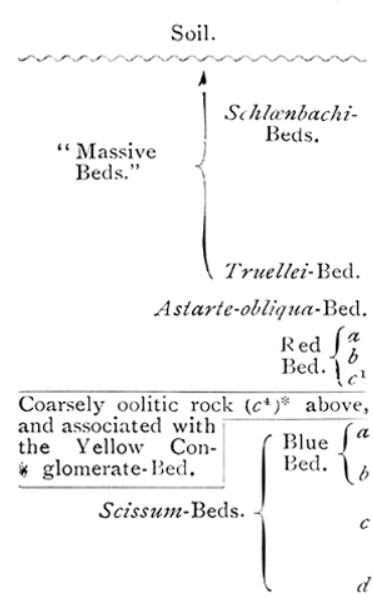

[* Belongs to the Red Bed.]

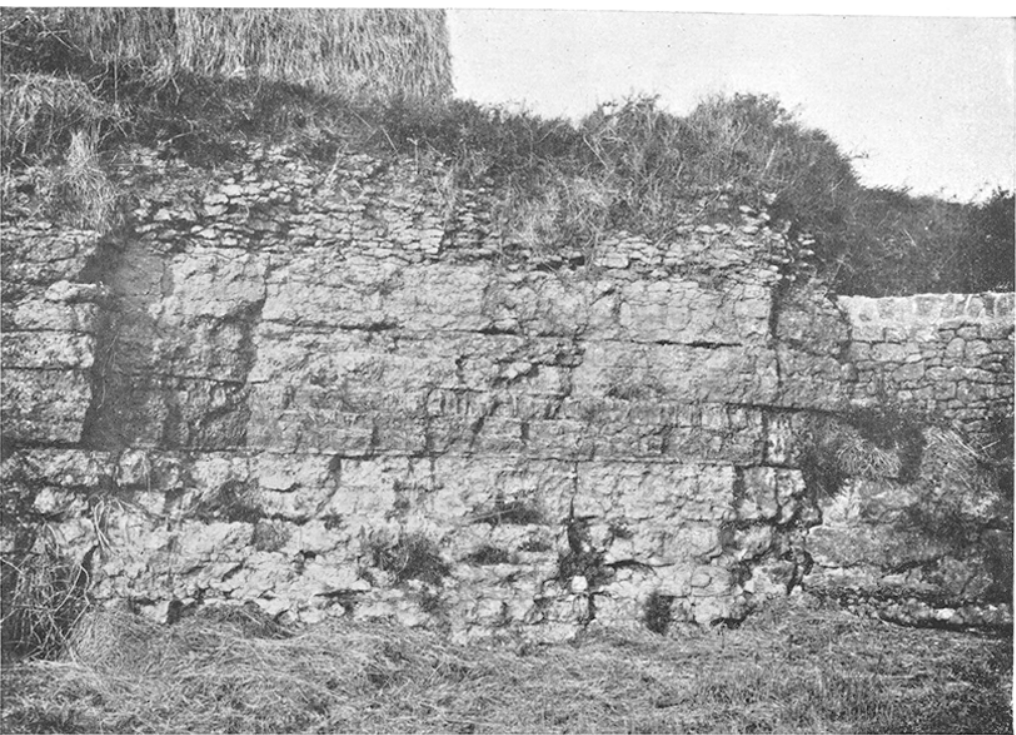

UpIODERS FARM QUakRY, LODERS, NEAR BRIDPORT.--L, Richardson. This picture show's very clearly the three "blocks" in which the Inferior Oolite occurs in this part of Dorset: at the top, (1) The Top-Beds (zigzagrgarantiane (incl.)); (2) "The Inter- 
From the Station there is a fine view of Eggardon. Hill $(828 \mathrm{ft}$. $)$. The party left by the $5.23 \mathrm{p} . \mathrm{m}$. train and arrived at Bridport at $5 \cdot 3 \circ$ p.m.

During the course of the evening, when reviewing the day's work and outlining that to be accomplished on the I $3^{\text {th }}$, the Director said that they were not going to investigate the district between Powerstock and Beaminster. Nevertheless, it was desirable that they should bave some knowledge of what the Inferior Oolite beds were like in that intervening region.

At the northern end of Powerstock village is a quarry in which the Inferior Oolite beds indicated in Fig. 5 are exposed. Beds XXV $a$ and $b$ are on the horizon of the Blue Bed of the Bell, Upton-Farm, and Chiselcombe Quarries. Attached to

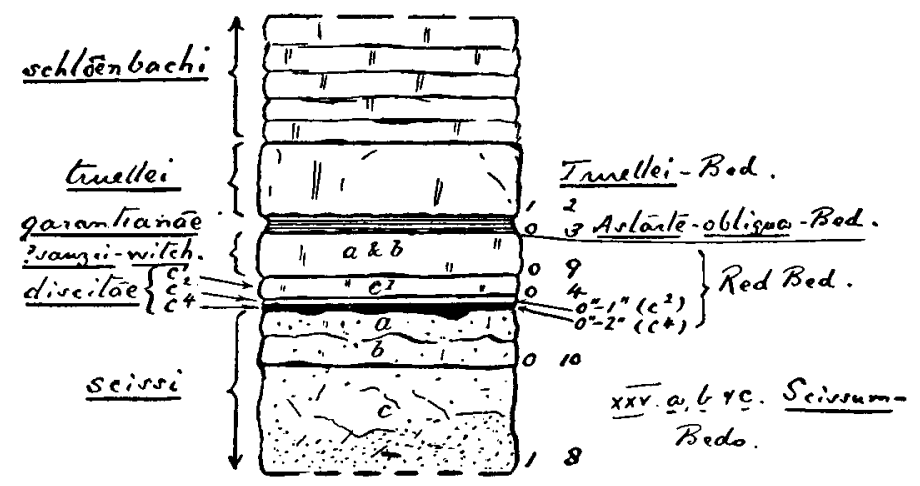

Fig. 5.-Vertical Section of the Inferior Oolite at POWERSTOCK.-L. Richardson.

the surface of XXV $a$ is the usual very coarsely-oolitic rock $\left(c^{4}\right)$ from which a number of specimens of Terebratula eudesiana S. Buckman have been obtained. Then comes an intermittent layer of brown clay $\left(c^{2}\right)$, followed by the Red Bed with its usual three layers $\left(c^{1}, b\right.$, and $\left.a\right)$, but the last two are not so distinct here from each other. The Astarte-obliqua-Bed is quite typical, full of the usual fossils, and is succeeded by the Truellei-Bed.

By the track-side on the hill-top to the north of Burcombe is a small opening. In it, at the bottom, are seen Scissum-Beds similar to those at Powerstock. Attached to their top, however, is a somewhat conglomeratic deposit, 3 in. thick, in which are fossils indicative of late scissi, ? ancolioceras and murchisone hemeræ. The intermittent coarsely-oolitic rock $c^{4}$ ( 0 to $\mathrm{I}$ in. thick) follows, the brown clay of Powerstock $\left(c^{2}\right)$ is lacking, but $c^{t}$ is recognisable (4 in., with occasional "snuff-boxes" at the base), as well as layers $a$ and $b$ of the $\operatorname{Red} \operatorname{Bed}(\mathrm{I} \mathrm{ft}$. I in.). The Astarte-obliqua-Bed is here conglomeratic, containing numerous 
limonite-coated pebbles and concretions. The Top Limestones (about I ft. seen) succeed.

On Mythe Hill, Mapperton, is a section differing from that at Burcombe only in a few details. The principal one is that $c^{2}$ is developed as a brownish-grey marly clay with numerous specimens of Belemnopsis blainvillei (Voltz), and contains occasional "snuff-boxes." Bed $c^{1}$ is usually 6 in. thick, and layers $a$ and $b$ of the Red Bed I ft. 5 in. thick. The Astarte-obliquaBed (o to 2 in. thick) follows, and is succeeded by $4 \mathrm{ft}$. of Top Limestones.

On the west side of the road, on Jack's Hill, is a quarry in which, at the base, is displayed the top stratum of the more massive lower portion of the Schlanbachi-Beds, followed by the upper more rubbly portion ( $3 \mathrm{ft} .9$ in.); this in turn by the Zigzag-Bed, quite typical, The Scroff (with Aulacothyris cucullata S. Buckman), and the Fullers'-Earth clay.

In the quarry on Coombe Down, nearer Beaminster, the Scissum-Beds are similar to their equivalents at the Mythe Hill Quarry and Burcombe, and likewise have a conglomeratic deposit (average 2 in. thick) containing fossils indicative of very late scissi, (?) ancolioceras and murchisone hemera, attached. The Discites-Beds are not satisfactorily exposed, but $c^{1}$ is rock very similar to that of the Bradford-Abbas "Fossil-Bed," and about 5 in. thick. Layers $a$ and $b$ of the Red Bed are thicker hereon an average II and Io in. respectively. The Astarte-obliquaBed is conglomeratic again, and o to $2 \mathrm{in.} \mathrm{thick.}$

In the district between Powerstock and Mapperton, around North Poorton, it will have been realised that the Inferior Oolite is thin. At Burcombe and Powerstock the rock between the Astarte-obliqua- and Scissum-Beds is under $2 \mathrm{ft}$. thick; a very different thickness to that which intervenes between the beds of corresponding date (garantiane and scissi) at Leckhampton Hill, Cheltenham-about i $90 \mathrm{ft}$.

The tenuity of the Series here around North Poorton is one reason why the main outcrop comes so close under that of the main mass of Fullers' Earth, Upper Greensand and Chalk, and is largely responsible for the remarkable land-relief of the tract. For streams, rising where the porous Greensand and impervious Fullers'-Earth clays meet, after they have cut through the hard Inferior Oolite, have rapidly excavated for themselves deep valleys in the Sands. The result is deep intersecting valleys and combes with high knolls and ridges in between, a district difficult for the agriculturist, and, therefore, little removed from its virgin condition.

APRIL I 2 TH.

Most of the members drove to Abbotsbury and saw the remains of the Benedictine Abbey, the Swannery, Chesil Bank, 
EXCURSION TO BRIDPORT, BEAMINSTER AND CREWKERNE. 69

and St. Catherine's Chapel on the hill.* On the drive back beautiful views were obtained of the cliffs by the coast.

APRIL I 3TH.

BeAMinster, BroAdWINDSOR, AND Whaddon Hill.

The members left the hotel at $9.3 \circ$ a.m. and drove to Beaminster. Here a short sojourn was made to enable those who wished to do so to look round the town and Church.

The drive was then continued to Barrowfield Quarry.

The Director said that the chief features of this section were : (I) the considerable thickness, for this district, of the rock that intervened between the Scissum-Beds and the horizon of the Astarte-obliqua-Bed, on an average $6 \mathrm{ft} .3$ in.; (2) the presence of rock of bradfordensis hemera (full of ammonites), joined on to the Murchisonce-Beds; and (3) the thinning out and coming in of layers $c^{1}$ and $a$ of Red Bed.

Above the Scissum-Beds come the Ancolioceras-Beds, $2 \mathrm{ft}$; Murchisonce-Beds, $2 \mathrm{ft}$. Io in., with numerous ammonites and specimens of Zeilleria anglica (Oppel) common along certain horizons, Variamussium pumilum (Lamarck) $[=V$. personatum (Goldfuss)], etc. ; and-joined on to the irregular surface of the latter-rock of bradfordensis hemera, 3 to 7 in. thick, full of ammonites.

On the very level surface of this block of beds rests a layer of brown clayey marl $\left(c^{2}\right)$, often highly ferruginous, to which succeed in turn the representatives of layers of $c^{d}$ and $a$ of the Red Bed$b$ appearing to be wanting.

The members were then taken to the southern end of the quarry and shown layer $a-a$ very hard brown grey-centred crystalline limestone, 7 in. thick. Here layer $c^{1}$ is wanting. The crystalline limestone was traced along the quarry-face northwards, and soon rock-similar to that of the Bradford-Abbas "FossilBed "- was observed coming in at its base. Still farther along ironcoated rubble makes its appearence at the top of the crystalline limestone; the limestone attenuates and also passes into a rubble, which coalesces with that above, and eventually the combined rubble is represented by a marly ferruginous deposit with only traces here and there of the irony rubble. The Discites-Bed $\left(c^{1}\right)$, which alone remains, increases in thickness to 6 in. In the northern side of the quarry - that facing south and on the righthand side as one enters the quarry-the crystalline limestone $a$ and the Discites-Bed $c^{1}$ are both present again.

The position of the Astarte-obliqua-Bed was readily perceived. The Top Limestones complete the section.

Many ammonites were collected here, principally from the

* An account of a similar day's excursion made by the Cotteswold Naturalists' Field Club will be found in their Proceedings, vol. xviii, pt. I (I9I2), pp. 35-38. 
rock of bradfordensis hemera and the top of the MurchisoneBeds.

Half-way between Beaminster and Broadwindsor Fullers' Earth (Knorri-Clays) was seen in the banks by the roadside. It contains specimens of Ostrea knorri (Voltz), Belemnopsis spp., Nuculana sp., Pteria (Oxytoma) sp., etc. Most of the specimens are covered with Serpulae and Webbince.

At Horn Park the recently-opened quarry was visited. There are two other quarries close to, but they have been abandoned for many years.

In the bank alongside the wheel-track just before the quarry is reached are seen the top-portion of the Scissum-Beds and the Ancolioceras-and Murchisone-Beds of like thickness and precisely similar to their equivalents at the Barrowfield Quarry. Then comes a change-bluish and brown well-ironshot limestone, crowded with ammonites, succeeds and represents a part of the "Building Stone " of Whaddon Hill. Similar rock forms the floor of the quarry. The equivalent of the Red Bed is $2 \mathrm{ft}$. I in. thick and consists of two beds of limestone (each $\mathbf{f} \mathrm{ft}$. thick), with a layer of limestone $\left(c^{1}\right)-\mathbf{I}$ in. thick and of discitce hemera-joined on to the base. The top of the Red Bed is relatively level, ferruginous, bored by annelids and "pitted" as at the coast section. In places, in irregularities and fissures, is a little ironshot rock-very similar to that composing layer $b$ of the Red Bed at Loders Cross. From one such infilling a small Oecotraustes ( $O$. aff. genicularis (Waagen) ; ? sauzei), which Mr. Spath says, as far as he knows, is not of zonal value but probably indicates sauzei, was obtained. The Astarte-obliqua-Bed is not represented by any deposit, at least none was detected, but its horizon was pointed out. Above come the Top Limestones, with brown clay (residual Fullers' Earth) at the top.

Here it was decided to make a change in the programme. In order to have ample time at the Conegar and Whaddon Hill sections it was agreed to omit the visit to the Misterton Lime Works, and to include it in the following day's itinerary.

After luncheon in Broadwindsor the members went into the deep lane-cutting (Conegar Hill) to the north of the village.

Investigations were commenced at the top of the section. The Top Limestones rest directly upon the bottom stratum of the Murchisona-Beds. There are no representatives of the Astarte-obliqua- or Red Beds, or of the "Building Stone" of Whaddon Hill,* while the greater portion of the Murchisona-Beds has been removed.

The Ancolioceras-Beds are of the same thickness, and similar

*BIue ironshot Concava-Beds (full of ammonites-Graphoceras aff. robustum $\mathrm{S}$. Buckman, $G$. undulatum S. Buckman, etc.) are to be seen in the bed of the road leading from Broadwindsor to Common Water, and thence to Tunnel Hill, and barely a quarter of a mile away in an east-south-east direction from the Conegar Hill section. 
to their equivalents at the Horn Park and Barrowfield Quarries. From the upper bed (XXIV.a) a specimen of Geyeria cf. evertens S. Buckman has been obtained. The Scissum-Beds are $7 \mathrm{ft}, 2$ in. thick. Below them is the equivalent to the Rusty Bed-a conspicuous layer of marl, brown and sandy at the top and dull grey and clayey at the base. Terebratula whoddonensis S. Buckman is common, and there are numerous specimens of the same species of ammonites as occur in the Rusty Bed of the BurtonBradstock district.

Below the Rusty Bed is sand-rock, about $\mathrm{I} f \mathrm{ft}$. 6 in. thick, similar to the very fossiliferous sandstone-bed (XXVI $b$ ) at Chideock Quarry Hill, and containing many specimens of thinkeeled ammonites (especially in the top portion), belemnites, Variamussium laviradiatum (Waagen), Rhynchonella cynocephala auctt., Rhyn. pentaptycta S. Buckman, etc. Below is sand-rock and sands displayed to a depth of at least $50 \mathrm{ft}$.

A sample of the sand from 4 to $5 \mathrm{ft}$. below the Rusty Bed was submitted to $\mathrm{Mr} . \mathrm{H}$. H. Thomas for examination. $\mathrm{He}$ very kindly reported as follows :

The sand, when the iron coating is removed, is pure white, extremely fine in grain, and consists of angular quartz, white mica, felspar, and a fair amount of chert. There is also a good heavy residue which may be easily separated by panning.

The heavy residue is dark in colour and contains a fair quantity of magnetite. The transparent minerals are : zircon with the usual habit, rutile in pale and deep yellow crystals and grains, garnet in irregular colourless to pink-brown grains, cyanite in colourless cleavage-fragments, tourmaline in small brown crystals and grains, often well-shaped, anatase in slightly turbid yellowish tables, staurolite a few grains only with the usual characters, and a small quantity of yellowish epidote.

As to the source of material there is little to guide one. The general absence of staurolite would suggest that Triassic rocks have not furnished much material, and there is nothing to suggest Old Red Sandstone. Cyanite is certainly not present to any great extent in the Triassic rocks of the south of England, and I cannot suggest the source of the great quantity present in the sample. On the other hand this mineral is abundant in the later sands of the west, and these are supposed to have got much of their material from the granite masses of Devon and Cornwall.

The lower portion of the Conegar Hill section is important because it shows the relationship of the Rusty Bed and associated deposits (the "Brachiopod-Beds" of Whaddon Hill) to the undoubted Sitssum-Beds above and the less-indurated portion of the Bridport Sands below.

The once much-visited quarries in the Top Limestones near Burstock Grange are now overgrown. About a quarter of a mile to the west of Broadwindsor, however, is an old quarry in which some Fullers' Earth, The Scroff (with Aulacothyris cucullata S. Buckman, not uncommon), the Zigzag-Bed (quite typical and full of ammonites), and $5 \mathrm{ft} .4 \mathrm{in}$. of Schlanbachi-Beds are seen. 
From Broadwindsor the members drove to Stoke Knapp and ascended Whaddon Hill.

The fine view over the Vale of Bridport was greatly admired.

Before dealing with the geography, however, attention was bestowed upon the "Brachiopod-Beds," which are exposed in the bank alongside the old road leading to the dilapidated limekiln. The Rusty.Bed (XXVIa), rich in specimens of Terebratula whaddonensis S. Buckman, Rhynchonella cynocephala auctt., and Aulacothyris blakei (Walker), was at once identified, together with the underlying, and here more than usually fossiliferous sandstone-bed-bed XXVI $b$.

Only the lower strata of the Scissum-Beds are exposed, and they indifferently. The total thickness of the Scissum-Beds is probably from $8 \mathrm{ft}$. 10 in. to $9 \mathrm{ft} .2$ in. (the beds in H. B. Woodward's section* numbered 7 and 8 by Mr. S. S. Buckman $\dagger$ ). Neither are the Ancolioceras- and Murchisonce-Beds exposed. At Barrowfield and Horn Park Quarries they are $4 \mathrm{ft}$. 10 in. thick. They are probably about the same thickness here, improbably less.

The members then went into the large and now disused quarry on the summit of the hill.

Here in descending order occur :

QUARRY ON WHADDON HILL.

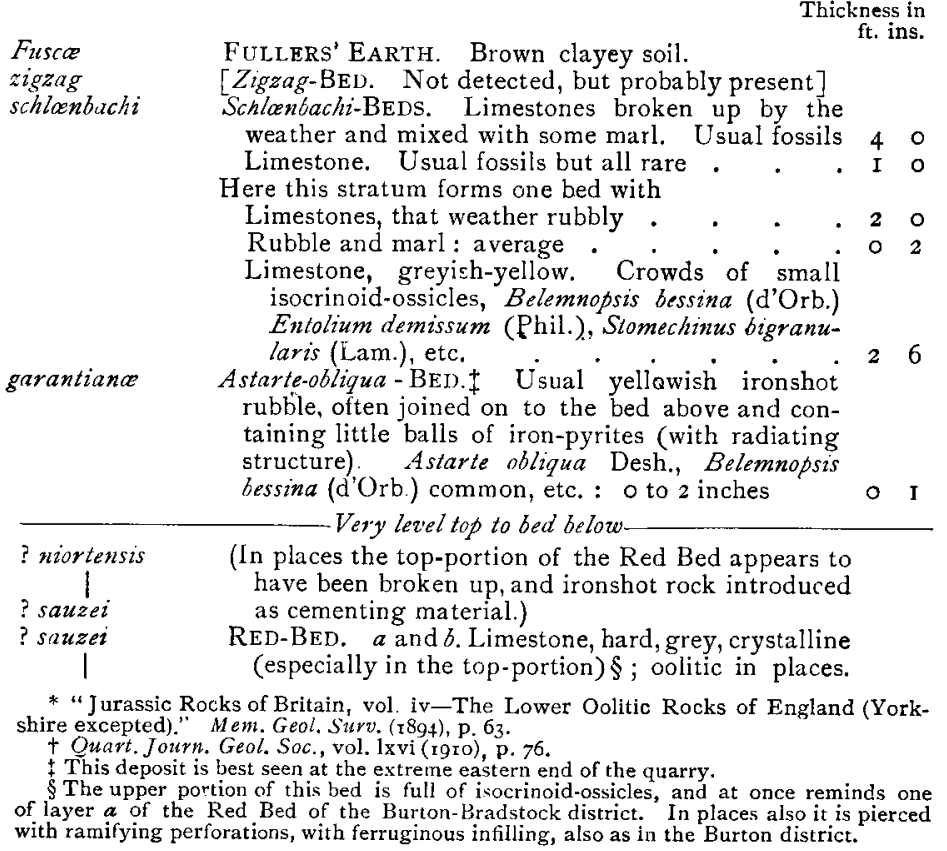


EXCURSION TO BRIDPORT, BEAMINSTER AND CREWKERNE. 73

Thickness in

ft. ins.

? witchellioe Belemnopsis sp., Pleurotomaria of P.-elongata group Acanthothyris sp., Zeillerin ? tenuis, Rich. and Upton, isocrinoid-ossicles (abundant in the upper portion). ? Rhabdscidaris sp. (radiole), ${ }^{*}$ etc. :

$2 \mathrm{ft} .8$ in, to $3 \mathrm{ft} .2$ in. shirbuirnio" $\quad$ Roadstone." Limestone, oolitic in the upper
portion ; ironshot in the lower. Occasional belemnites, Gryphoca sublobata Deshayes.

discitaet

$c^{1}$ Limestone, well-ironshot and similar to that forming the top of the "Building Stone," is here and there found joined on to the base of the Roadstone. Lima etheridgei, Wr., Rhynchonella Sp.: 0 to 3 in.

$c^{2}$ "Waste." Brown marl with irony layers." $B e$ lemnopsis blainvillei (Voltz) common, Rhynchonella sp. : o to 3 in.

discitre, concavi,

"Building Stone" i.mestone, well ironshot and, at bradfordensist certain horizons, full of ammonites. Seen, 2 ft. 6 in., according to Mr. Buckman .

murchisone Murchisone-BeDs. Not now exposed.

ancolioceras Ancolioceras-BEDS. Not now exposed.

scissi Scissum-Beds. Sandstones, not well exposed.

Sandstone, hard, calcareous. Pachyteuthis sp., Aula-
cothyris blakei (Walker), Rhynchonella cynocephala
auctt., Terebratula whad donensis S. Buckman auctt., Terebratula whaddonensis S. Buckman .

opalinformis

? opaliniformis rather shaly in the upper portion (where it contains pieces of whitish limestone) and dull grey and more clayey in the lower. Involute Phydellice, Aulacothyris blakei (Walker), Rhvn. cynocephala auctt, Terebratula whaddonensis S. Buckman, common, etc. - * forming

bed and weathering whitish in places. Numerous ammonites (involute Pleydellia, Hammatoceras subinsigne (Oppel), etc.), Megateuthis sp., Pholadomya sp., Pleuromya, Pleria sp., Variamussium laviradiatum (Waagen) Aulacothyris blakei (Walker), Rhyn. cynocephala aucte. Rhyn. opalina Quenstedt, Rhyn. penlaptycta Buckman, Ter. whaddonensis Buckman, Zeilleria whaddonensis Buckman, Serpula tricarinata auctt., Isocrinus : average . .

Sandrock, with most irregular base, Serpula tricarinata common, but few other fossils : I $\mathrm{ft}$. to I ft. 4 in.

Yellow sands and sand-burrs. Serpula tricarinata auctt.: seen . . .

Some considerable time was spent in an attempt to find definite palæontological evidence of the Astarte-obliqua-Bed; but, while rubble similar to that of the Astarte-obliqua-Bed of

* Proc. Cotteswold Nat. F. C., vol. xviii, pt. I (tgra), p. 81. Recorded then as coming from the Schlonbachi-Beds.

Includes post-discita.

$\mp$ According to Mr. S. S. Buckman. Mr. Buckman has given a detailed account of the "Building Stone" in the Quart. Journ. Geol. Soc., vol. 1xvi (Ig10), pp. 75-77. 
the Burton district was seen here and there with pieces of Belemnopsis bessina (d'Orb.), the search was unsuccessful.*

From the summit of the Whaddon Hill, looking south, is a fine view cver the Vale of Bridport. On the immediate right is Lewesdon Hill ( $894 \mathrm{ft}$.), with its dark plantation. South-westwards is seen the sea at Charmouth, and then follow the longtopped, slightly easterly-inclined Stonebarrow Hill, Golden Cap, and, more round, between the conical Colmer's Hill and Chideock Quarry Hill, Thorncombe Beacon. A little to the east-of-south is seen the town of Bridport, with the cliff at West Bay just showing beyond. Further east, Shipton Hill is a readilyrecognised landmark; while beyond is the high ground above Abbotsbury. From above Loders the ledge formed by the Inferior-Oolite rocks is easily followed round to the fir-crowned Coombe Down Hill. At the back stretches the escarpment of the Upper Greensand and Chalk, with its prominent spur-the desolate-looking Eggardon Hill. Occupying the centre of this great circle of hills is the undulating and fertile Vale of Bridport.

I ooking northwards, on the left, westwards beyond Broadwindsor village, is the valley traversed by the main L. \& S.W. R. Beyond, are the hills west of Chard. Due north, in the hollow, is Mosterton, and a little to the left (amongst the trees) the tower of North Perrott Church. Over the eastern slope of the hill to the west of Mosterton is the position of Crewkerne, and, beyond, Ham Hill. Nearer at hand is "Tunnel Hill," as it is locally called, formed of Chalk and Upper Greensand, which passes eastwards into the main Cretaceous upland. Salway.

The return drive to Bridport was by way of Kingsland and

Tuesday, Aprit I4TH.

Misterton and North Perrott.

The last day was devoted to an excursion to the country beyond Tunnel Hill-to Misterton, North Perrott, and Crewkerne. The members left the hotel, Bridport, at 9.1 5 a.m., and soon accomplished the journey to the Lime Works, Misterton.

Here $7 \mathrm{ft}$. of Top Limestones are seen. Attached to their base is the representative of the $A$ starte-obliqua-Bed (garantiance) - creamcoloured limestone, 4 in. thick, with few fossils, but containing the usual rich-yellow ochreous inclusions in the lower portion.

The Garantiana-Bed rests upon a waterworn, level and irony surface of the bed below. This bed is of ancolioceras-murchisone hemeræ; the greater portion of the earlier date. The quarrymen apply the names "Blue Bed," "Red Bed," and "Grey Bed" to its three component strata (in descending order), and also call the last-which is full of fossils - the "Cockle Bed." The "Blue Bed" ( $\mathrm{I} \mathrm{ft}$. ) is of murchisone or ancolioceras hemeræ, and has

* Another visit was paid by the Director to the locality on April 16 th, when he was successful in finding in the rubble, Astarte obliqua, Desh., and several other fossils. 
yielded Pseudoglossothyris simplex, (J. Buckman). From the "Red Bed " ( $8 \mathrm{in}$.) has been obtained a specimen of Geyeria $\mathrm{cf}$. evertens, S. S. Buckman, and from the "Grey Bed" ( $\mathrm{I} \mathrm{ft} . \mathrm{I}$ in.) a specimen of ? Hyattina aff. brasili S. Buckman-ammonites indicating, according to Mr. Buckman, ancolioceras hemeræ.

Attached to the top of the "Blue Bed" is hard bluish-grey ironshot rock, $\circ$ to 4 in. thick, which is either of bradfordensis or discite hemera.

The next stop was at Slade's Quarry (down Trindlewell Lane), North Perrott. Beds equivalent to the Grey, Red and Blue Beds of the Misterton section, $2 \mathrm{ft} .8 \mathrm{in}$. thick, are exposed, and a Geyeria sp. was obtained from $\mathrm{x} f \mathrm{ft}$. I in. below the base of the Garantiana-Bed. The rock of garantiance hemera is $2 \mathrm{ft}$. 5 in. thick here and very rich in fossils. These include Rhynchonella parvula Desl., Ataphrus acmon (d'Orb.), and varieties, etc. In an old shallow quarry under the hedge in the field to the west the Zigzag-Bed and The Scroff may be seen by a little excavating, and the Fullers'-Earth clay.

The last section visited was that in the quarry at the western end of the Manor House grounds, North Perrott-that referred to by H. B. Woodward as "by New Hall, west of North Perrott Church."*

Concerning the quarry, Woodward wrote that it shows

"about I $8 \mathrm{ft}$. of false-bedded shell-limestones, interbedded with buff sands and sandy limestones, that . . occur locally in the upper part of the Midford Sand in this district and are well represented at Ham Hill. The shell fragments are mostly indeterminable as to species, consisting of Ostrea, Pecten, and Avicula ; but Mr. Rhodes obtained Pecten demissus and Belemnites voltzi (?)."

A photograph of this section is reproduced on Plate 9 .

Quarry at North PERrott Manor House. Thickness in

\begin{tabular}{|c|c|}
\hline scisst & $\left\{\begin{array}{l}\text { I. Bluish-grey and pale yellow, very fine-grained } \\
\text { micaceous sandy clay ; Belemnites sp., Aulaco- } \\
\text { thyrisblakei (Walker), Rhynchonella cynocephala } \\
\text { auct., Terebratula cf. Ter.-haresfieldensis: } \\
\text { group: about. }\end{array}\right.$ \\
\hline ? scissi & $\begin{array}{l}\text { 2. Limestone, fairly regular band of whitish-looking } \\
\text { sandy limestone, Ostrea sp. }\end{array}$ \\
\hline
\end{tabular}

3. Yellow micaceous sandy clay, weathering a palegrey colour, with rubbly limestone and rolled and often phosphatised fossils in the lower portion; Pleydeliza aalensis (Zieten) at very base; Belemnites irregularis Schloth. (rolled), Ostrea 3 spp., Aulacothvsis blakei (Walker), Zeillevia whaddonensis S. Buckman, Rhynchonella cynocephala auctt., Rhynchonella pentaptycta S. Buckman : about . . . .

Stone"
(brobably
moorei) $\quad \begin{aligned} & \text { 4. Limestone, brown, practically made up of shell- } \\ & \text { fragments, shaly in places, very hard, blue- } \\ & \text { centred and crystalline in others, irregularly } \\ & \text { bedded; Lytoceras sp. (large and not in- } \\ & \text { frequent) : about . . }\end{aligned}$

* "The Jurassic Rocks of Britain, etc.," vol. iv (1894), p. 71. Mem. Geol. Surv. 
On first entering the quarry the greyish-looking sandy clay on top of the "Perrott Stone" might easily be put down for Fullers' Earth. It contains ammonites, including Pleydellia aalensis (Zieten) which soon prove otherwise.

As far as can be seen at present it would appear that after the formation of the Perrott Stone (probably moorei) deposition was slow, for the greyish-looking sandy clay (aalensis-opaliniformis) contains, in the lower portion, rubbly limestone and rolled and often phosphatised fossils; also specimens of Pleydellia aalensis (Zieten) and brachiopods such as occur in the lower part of the Brachiopod-Beds of Whaddon Hill. The $4 \mathrm{ft}$. of sandy clays are of scissi date.

The visit to Barrows Hill Quarry-or "Little Silver," as it has come to be known amongst brachiopodists-was omitted; but the Director said that it showed the top of the Perrott Stone, yellow and grey sandy clay (10 in.) similar to that of aalensisopaliniformis date in this quarry (at North Perrott), succeeded by sandy clays with subordinate beds of greyish-white limestone (seen $8 \mathrm{ft}$.) to about the lower half of which the highest deposits seen in this quarry were equivalent.

Lunch was obtained in Crewkerne, after which a visit was paid to the Parish Church, a fine edifice in the Perpendicular style. The series of gargoyles above the south porch, representing a band of musicians, was specially noted and admired.

Bridport was reached about 3.30 p.m., giving the members ample time to catch the 4.30 p.m. train to town.

\section{REFERENCES.}

Geological Survey Map (I inch $=4$ miles), Sheets 18 and 22.

Geological Survey Map (I inch $=I$ mile), Sheets xvii (price IIs.), and xviii. Old Series.

I822. DE LA BECHE [Sir] H. T.-"Remarks on the Geology of the South Coast of England from Bridport Harbour, Dorset, to Babbacombe Bay, Devon." Trans. Geol. Soc., series 2, vol, i, p. 306.

1822. Conybere, Rev. W. D., and PhILlips, W.- "Outlines of the Geology of England and Wales." Pp. 236 and 256.

1835. BuCKI.AND, Rev. Prof. W., and DE LA BEChe [Sir] H. T.-"On the Geologv of the Neighbourhood of Weymouth and the adjacent parts of the Coast of Dorset." Trans. Geol. Soc., series 2, vol. iv, p. $3 I$

I856. WRIGHT, T.-"The Palæontological and Stratigraphical Relations of the so-called Sands of the Inferior Oolite." Quart. Fourn. Geol. Soc., vol. xii, pp. 292-325 (pp. 3I0-3I2).

1856-8. OPPEL, Dr. A.- "Die Juraformation Englands, Frankreichs und des Südwestlichen Deutschlands."

2860. DAMON, ROBERT.- "Handbook to the Geology of Weymouth and the Island of Portland " (Ist ed. 1860, 2nd ed. I\$80, 3rd ed. I888).

1860. WRIGHT, T.- "On the Subdivisions of the Inferior Oolite in the South of England, compared with the Equivalent Beds of that 


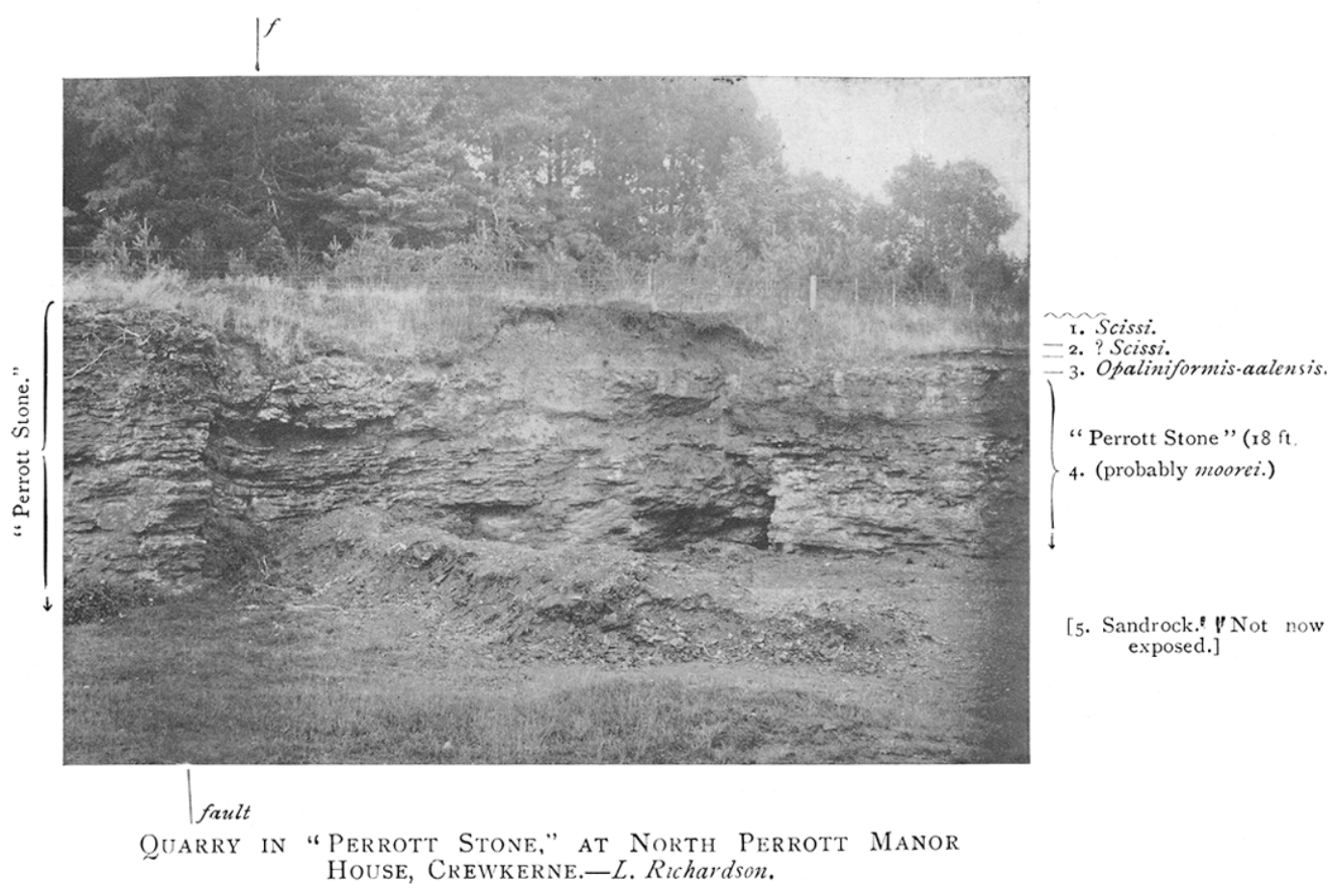

To face page 76 . 
Formation in Yorkshire." Quart. Fourn. Geol. Soc., vol, xvi, pp. $1-48$ (p. 47).

I863. DaY, E. C. H.- "On the Middle and Upper Lias of the Dorsetshire Coast." Id., vol, xix, pp. 278-297 (p. 287).

I879. Buckman [Prof.] James.- "On the so-called Midford Sands." Id.,

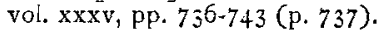

188I. BUCKMAN, S. S.- "A Descriptive Catalogue of some of the Species of Ammonites from the Inferior Oolite of Dorset." Id., vol. xxxvii, pp. 588-608.

I88 . BUCKMAN [Prof.] JAMES.-."On the Trigonia bella [Lycett], from [the ferruginous bed of the Inferior Oolite] Eype, near Bridport, Dorset." Proc. Dorset Nat. Hist. and Antiqu. F.C., vol. v, pp. $154-156$.

1885. HUDLESTON, W. H., and WOODWARD, H. B.-"Excursion to Sherborne and Bridport." Proc. Geol. Assoc., vol. ix, pp. I87-209. (Part 4, price Is.)

I887. Hudieston, W. H.- "Gasteropoda of the Inferior Oolite," part I. Monogr. Palceont. Soc., pp. 26-40.

I889. BuCkMAN, S. S.- "On the Cotteswold, Midford, and Yeovil Sands, and the Division between the Lias and Oolite." Quart. Fourn. Geol. Soc., vol. xlv, pp. 440-473.

1889. WALFORD, E. A.-"On some Bryozoa from the Inferior Oolite of Shipton Gorge, Dorset," part I. Ji, vol. xlv, pp. 56r-574, and plates xvii-xix, part ii. Id., vol. 1, pp. $72-78$ and plates ii-iv.

I89o. BuCKMAN, S. S.-" On the so-called "Upper Lias" Clay of Down Cliffs." Id., vol. xlvi, pp. 518-521.

I8go. Solcy, H. S.-- "The Geology of Bridport." Proc. Dorset Nat. Hist. and Antiqu. F.C., vol. xi, pp. Iog-I I 7 .

I890. and WALKER, J. F.— "Note on the Fault in the Cliff west of Bridport Harbour." Id., pp. II 8-I2 I, also Ret. Brit. Assoc. for 1890 (I89I), pp. $799-800$.

I89I. BuCKMAN, S. S.-"The Ammonite Zones of Dorset and Somerset." Rep. Brit. Assoc (Cardiff), pp 655-656; and Geol. Mag., dec. 3, vol, viii, pp. 502-504.

I892. WaLkER, J. F.-"On Liussic Sections near Bridport, Dorsetshire." Geol. Mag., dec. 3, vol. ix, pp. 437-443.

I892. Woodward, H. B. "Notes on the Geology of Crewkenne." Proc. Somerset Arch. and Nat Hist. Soc., vol, xxxvii, pp. 60-69.

I893. Buckman, S. S.-" The Top of the 'Inferior Oolite' and a correlation of "Inferior Oolite' Deposits." Pruc. Durset Nat. Hist. and' Antiqu. F.C., vol, xiv, pp. 37-43.

I893. Hinde, G. J.- "A Monograph of the British Fossil Sponges," vol, i ; "Sponges of the Jurassic Strata," part 3, pp. I89-254, and plates x-xix. Monogr. Palceut. Soc.

1893. WoodWARD, H. B.--"The Jurassic Rocks of Britain," vol. iii "The Lias of England and Wales (Yorkshire excepted)." Mem. Geol. Surv.

1894. - $-I d$., vol. iv. "The Lower Oolitic Rocks of England (Yorkshire excepted)." Mem. Geol. Sury.

I898. Blake, J. F., Hudleston, W. H., and Buckman, S. S.-"Excursion to Bridport and Weymouth." Proc. Geol. Assoc, vol. xv, pp. 293. 304 (Part 8, price 9d.).

I903. BUCKMAN. S. S.-- The Toarcian of Bredon Hill, and a Comparison with Deposits elsewhere." Quart. Fourn. Geol. Soc.. vol. lix, pp. $445-458$

1908. RICHARDSON, L., and PARIS, E. T.-." On the Stratigraphical and Geographical Distribution of the Inferior Oolite Echinoids of the 
West of England." Proc. Cotteswold Nat. F.C., vol. xvi, part 2, pp. I5I-193, and plates xvi-xvii.

rgro. Hudleston, W. H._-" Dorset-Inland." Geologv in the Field, part 2, pp. 365-38r.

igro. Monckton, H. W.-." The Dorset Coast." Td., pp. 382-413.

rgIo. Buckman, S. S.--"Certain Jurassic (Lias-Oolite) Strata of South Dorset and their Correlation." Quart. Fourn. Geol. Soc., vol. 1xvi, pp. 52.89 .

1910. _Lertain Jurassic ("Inferior Oolite') Species of Ammonites and Brachiopoda." Id., pp. 90-108, and plates ix-xii.

1912. RIChardson, L., and BUTT, Rev. WALTER-"Excursion to Bridport, Dorset." Proc. Cotteswold Nat. F.C., vol. xviii, part I, pp. $3^{r-38}$, and plates iv-vi.

19I2. _ and PARIS, E. T._-"On the Stratigraphical and Geographical Distribution of the Inferior Oolite Echinoids of the West of England : Supplement." Id., pp. 73-82, and plate viii.

\section{REPORT OF AN EXCURSION TO GREENHITHE AND STONE.}

Saturday, April 25 Th, IgI4.

By S. Priest, F.G.S., Director of the Excursion.

ABout 40 members arrived at Greenhithe at 2.37 p.m., and proceeded to London Road, where the chief features of the district were briefly described.

In the neighbourhood of Greenhithe the Chalk rises to about Ioo ft. above O.D., and at this height is overlain by a well defined terrace of gravel, extending from Stone Place, $x_{4} 4 \mathrm{ft}$. above O.D., to Dartford Brent. The gravel terrace is intersected by two valleys which unite near Stone Court Cottages, where the surface falls to the $25 \mathrm{ft}$. contour. The thickest part of the gravel lies roughly along the line of London Road. In the Stone Court pits (east and west of Cotton Lane) a few feet of Thanet Sand separate the Pleistocene deposits from the Chalk, but along its northern limit the gravel rests directly upon the Chalk, and its base contains much coarse material, principally large unrolled chalk-flints. The drift appears to lie in a channel excavated in the Chalk after the demudation of the overlying Tertiaries.

The constituents of these gravels are principally flints and cherts derived from the Lower Greensand, Chalk and Eocene 